\title{
THE "COLONIZATION" OF EAST GERMANY ?: A COMPARATIVE ANALYSIS OF GERMAN PRIVATIZATION
}

\author{
HEATHER M. STACK \\ INTRODUCTION
}

Privatization is a global phenomenon. ${ }^{1}$ For many developing countries, and countries formerly controlled by the Soviet Union, privatization represents the key to prosperity. ${ }^{2}$ The recent transformation of the $\mathrm{E}$ ast $\mathrm{German}^{3}$ economy is perhaps the paradigm of this trend; the largest privatization to date, it is viewed as the most successful of its kind. ${ }^{4}$ Indeed, most commentators view the

1. At the beginning of the 1990 's at least 83 countries were undergoing some form of privatization. See A nna Gelpern \& Malcolm Harrison, Ideology, Practice, and Performance in Privatization: A Case Study of Argentina, 33 HARV. INT'L L.J. 240, 240 (1992); see also Mary M. Shirley, Privatization and Performance, 17 HASTINGS INT'L \& COMP. L. REV. 669, 671-73 (1994) (describing the great increase in privatizations in the 1990's). In this Note, privatization refers to the transfer of state-owned enterprises into the private sector.

2. See, e.g., Christopher adam et al., Adjusting Privatization: Case StudIES FROM DEVELOPING COUNTRIES 116-117, 163 (1992) (noting that improving efficiency and stimulating development have been the goals of privatization in Jamaica and Sri Lanka); Shirley, supra note 1, at 672 (citing the wish to make a country's economy and citizens "better off" as the major reason for privatizing); Mary M. Shirley, The What, Why, and How of Privatization: A World Bank Perspective, 60 FORDHAM L. REV. S23, S25-27 (1992) (setting forth enhanced efficiency and improved use of public resources as reasons for privatizing).

3. Throughout this Note, the terms "E ast Germany" and "E ast Germans" are used to refer to the territory and citizens of the former German Democratic Republic both before and after reunification.

4. See, e.g., James H. Freis, J r., An O utsider's Look into the Regulation of Insider Trading in Germany: A Guide to Securities, Banking and Market Reform in Finanzplan Deutschland, 19 B.C. INT'L \& COMP. L. REV. 1, 8 (1996) (stating that post-unification Germany has reasserted itself as an economic power); A lexander R eus, Eastern Germany Report: Investment Incentives in the New Länder, 4 U. MIAMI BUS. L.J. 1, 2-3, 6-7 (1994) (noting that the former German Democratic Republic's climate, market size, central position within Europe, and privatization incentive programs have indeed resulted in "high investment levels in Eastern Germany"); Edward Mortimer, The Ballot Box Is Here to Stay, FIN. TIMES, Dec. 23, 1995, available in 1995 WL 1167853, at *7 ("German unity can already be proclaimed an irreversible success."); Privatizations A re D eemed Success in Eastern Germany, WALL ST. J. EUROPE, May 25, 1993, available in 1993 WL-WSJE 2038759, at $* 1$ (reporting view that most East German companies were privatized successfully); John Hall U do Ludwig, East Germany's Transitional E conomy, CHALLENGE, Sept. 
East German privatization as a model-a "triumph of the market" $^{5}$ - to be emulated worldwide. ${ }^{6}$

By traditional measures, the transformation in Germany has been a success. Gross domestic product (GDP) is at a respectable level, ${ }^{7}$ the formerly state-owned enterprises of the German Democratic Republic have been transferred into private hands, ${ }^{8}$ and reunified Germany is once again a relatively prosperous nation. However, a complete evaluation of the German program's success should account for the difference in benefits enjoyed by $E$ ast and W est Germans. Six years after reunification, there remains a "deep economic and emotional divide between east and west." 9 The East German people still do not trust their new democratic government. ${ }^{10}$ They are also generally insecure in their land ownership, are much more likely to be unemployed than they were under the communist regime, and lack ownership in the formerly state-owned enterprises that have been transferred into private

1, 1994, available in 1994 WL13169674, at *26 (observing that the privatization of East German enterprises "can be considered successful because of its rapidity and completeness.").

5. John Eisenhammer, Germans Pay a Price for Freedom Fire Sale, INDEPENDENT (London), Jan. 8, 1995, at 7.

6. By 1995, German officials were already acting as consultants on privatization for about thirty countries around the world. See Mary Williams Walsh, National A genda: Going Private- the Profit and the Pain, L.A. TIMES, Jan. 10, 1995, at H1. See also supra note 4 and accompanying text.

7. A Ithough Germany's GDP fell in 1992 and early 1993, it has rebounded, evidence of a strong recovery after the first years of reunification and following an unrelated worldwide recession. See ORGANISATION FOR ECONOMIC COOPERATION \& DEVELOPMENT (OECD) ECONOMIC SURVEYS 1994-1995: GERMANY 1, 3, 5. In 1994, Germany's GDP rose by 2.9 percent, with 9.2 percent of the increase coming from the growth in East Germany. Institutes See 3 per cent Rise in German GDP this Year, AGENCE FRANCE PRESSE, A pril 11, 1995, available in LEXIS, News Library, Afp File.

8. By the end of 1994, almost all of the East German enterprises earmarked for privatization were owned by the private sector. See Ellen Hasenkamp, German Privatization A gency Ceases Work, CHRISTIAN SCI. MONITOR, Dec. 29, 1994, at 9; Walsh, supra note 6 , at $\mathrm{H} 1$.

9. Matt Marshall, E. Germans Shut Out in Estate Deals; Privatization Halted for Review by Court, WASH. POST, Feb. 17, 1995, at A 32; cf. A lan Cowell, It's Young vs. Old in Germany as the Welfare State Fades, N.Y. TIMES, June 4, 1997, at A 1 (describing relationship between $E$ ast and West as "divided still by what some call a spiritual and mental version of the Berlin Wall").

10. See, e.g., Erik Kirschbaum, East IS East and West Is West, but Will the Twain Ever M eet?, WASH. TIMES, July 28, 1996, at A 8 (explaining that the citizens of E ast Berlin and of the new eastern state of Brandenburg, largely because of mistrust for the government and frustration over reunification, defeated a referendum to unite Berlin with Brandenburg). 
hands. ${ }^{11}$ For East Germans, privatization has created a mistrust of government, a withdrawal from economic matters, and a general social divide between citizens of the East and West. The East Germans' position has led some commentators to label the transformation a "colonization"12 or "occupation" 13 of East Germany.

Collectively, these problems reflect the larger challenge of achieving long-term economic and political integration in a reunited Germany, made more difficult by "fairly widespread . . . malaise" across East Germany. ${ }^{14}$ This discontent continues to fuel political and social instability today. While it is unlikely to undercut markets and democracy in Germany, ${ }^{15}$ it should serve as a warning sign for other Eastern European countries and developing nations who are now privatizing. ${ }^{16}$ The German experience has been quite successful for many, but the goal of long-term integration has suffered, largely because of the legal structures chosen to implement privatization. These structures did not focus sufficient attention on the distributional consequences of privatization.

While the German privatization process has been successful in many aspects, its architects could have employed different legal structures which would have better served the important goals of long-term integration and political stability. ${ }^{17}$ The three most salient shortcomings of the German privatization process are at their

11. See infra Part II.

12. See Thomas A. Baylis, Transforming the East German Economy: Shock Without Therapy, in FROM BUNDESREPUBLIK TO DEUTSCHLAND 77, 86 (Michael G. Huelshoff et al. eds., 1993); see also Hasenkamp, supra note 8, at 9.

13. Dan van der Vat, Freedom Was Never Like This 9 (1991).

14. Herbert L. Bernstein, Germany's Unification and its Discontents, DUKE L. MAG., Winter 1995, at 4, 5.

15. East Germany had the distinct advantage (or disadvantage) of reunification with a democratic nation that had a strong market economy. Because of its marriage to a stable western country, democracy and the economy have not been in serious danger. Other countries in Eastern Europe coping with the collapse of the Soviet Empire have been left to conduct the transformations in their societies without a western counterpart. While Germany is unique in this regard, the German experience may nonetheless be of value to countries undergoing a unitary privatization. See infra Part III.

16. See, e.g., A my L. Chua, The Privatization-Nationalization Cycle: The Link Between Markets and Ethnicity in Developing Countries, 95 CoLUM. L. REV. 223, 262-84 (1995) (arguing that the privatizing nations of the world are in danger of reverting to nationalization in response to ethnic and economic problems associated with privatization).

17. German privatization, of course, was conducted at a time of great political and social turmoil in Germany and throughout Europe. This Note is written with the benefit of hindsight; the Germans deserve credit for completing a revolutionary task with relative success. 
heart distributional: high unemployment in the $\mathrm{E}$ ast, the nature of restitution, and the lack of $E$ ast German ownership in the newly privatized enterprises. Examining these shortcomings can provide valuable lessons for today's privatizers.

This Note seeks to distill useful lessons from the successes and shortcomings of German privatization. To do this, it evaluates German privatization from a comparative perspective. While no other nation faces Germany's unique circumstances, comparison is valuable because all privatizations, in essence, involve the transfer of ownership of land and enterprises from public to private hands. This Note examines privatization processes that have been undertaken in two very different contexts. The first involves the voucher privatization and strict restitution policies implemented in the former Czechoslovakia. By instituting these policies, the government of the Czech Republic has more fully integrated its citizens into its new economy, resulting in a stable democracy and an economy fully supported by its citizens. The second involves privatization efforts in Latin A merica and Southeast A sia. The problems faced by Latin A merican and Southeast A sian nations today demonstrate the dangers of failing to treat distribution and integration as primary objectives of privatization. A $n$ examination of the privatization process in these regions demonstrates a central lesson: the distributional consequences of privatization should be given primary attention.

Part I of this Note discusses the history and the legal structure of reunification and privatization in Germany. Part II examines the consequences of German privatization and offers a critique of the German process, paying particular attention to its distributional effects and its effects on political integration. Part III explores comparative alternatives to the German approach, focusing first on the Czech model and then analyzing the results of privatization in L atin A merica and Southeast A sia. This N ote concludes that, in order to produce stable market economies through privatization, distributional consequences of the process deserve priority. 


\section{The legal Structure of German Privatization AND REUNIFICATION}

\section{A. Political and E conomic U nification}

In the aftermath of World War II, Germany was divided into two countries: the German Democratic Republic (GDR) in the east and the Federal Republic of Germany (FRG) in the west. The Berlin Wall, erected in 1961, completed the division of the two Germanies. The Wall symbolized more than just physical separation; it represented political nonrecognition, economic isolation, and cultural division between the East and the West. A fter forty-five years of bitter division, the opening of the Berlin Wall and the East German border on November 9, 1989, was a shock to the world. ${ }^{18}$

J ust as surprising was the almost immediate reunification of the two Germanies. The government of the $F R G$ and the newly elected democratic government of the GDR ${ }^{19}$ both wanted to proceed quickly with reunification. ${ }^{20}$ In a process that could only be described as "shock therapy," 21 German leaders seized the opportunity created by the fall of Communism to make extraordinary changes, and the two Germanies were politically and economically unified in one swift motion.

Political reunification took place on 0 ctober 3, 1990, pursuant to A rticle 23 of the Basic Law of the Federal Republic of Germany. ${ }^{22}$ Under A rticle 23 , the decision to reunify was a unilateral

18. For a good account of pre-unification German history, see generally HENRY A shby Turner, JR., The Two Germanies Since 1945 (1987) (detailing the postwar histories of East and West Germany), and for an interesting discussion of the period surrounding reunification, see PHILIP ZELIKOW \& CONDOLEEZA RICE, GERMANY UNIFIED AND EUROPE TRANSFORMED (1995) (examining the events of reunification in connection with the political climate in Europe and the former Soviet U nion).

19. On March 18, 1990, the first democratic elections took place in the former GDR. The East Germans elected a democratic government; the Christian Democrats (CDU), the conservative party of FRG Chancellor Helmut Kohl, and its allies gained a majority. See $M$ anfred Kuechler, Political Attitudes and Behavior in Germany: The Making of a Democratic Society, in FROM BUNDESREPUBLIK TO DEUTSCHLAND, supra note 12, at 33, 45-46.

20. See Wolfgang Schäuble, Der Vertrag [The Treaty] 140 (1991).

21. Baylis, supra note 12 , at 77 .

22. See GG art. 23 ("The Basic Law applies to the lands of Baden, Bayern, Bremen, West Berlin, Hamburg, Hessen, Niedersachsen, Nordrhein-Westfalen, R heinland-Pfalz, Schleswig-H olstein, W ürttemberg-Baden and Württemberg-Hohenzollern [the lands of the FRG in 1949]. In the remaining parts of Germany, a vote is required in order to adopt 
act by the GDR. The Treaty of U nification ${ }^{23}$ incorporated the negotiated terms of reunification and affected the mass transfer of the FRG's laws into East German territory. ${ }^{24}$ Political reunification was completed with the broad transfer of laws and the accession of the GDR to the FRG.

While political unification was completed in a few quick steps, ${ }^{25}$ the economic changes that culminated in the mass privatization of $E$ ast German enterprises involved a more complicated social and legal reorganization. The process of economic unification began with the signing of the Treaty on the M onetary, Economic and Social U nion on M ay $18,1990 .{ }^{26}$ This Treaty formally

the Basic Law.") (author's translation). The Grundgesetz was the law of the land in the Federal Republic during the time that the two Germanies were separated. A constitutional assembly named the FRG governing document Grundgesetz instead of Verfassung (constitution) because it wanted to preserve the concept of a Verfassung for the time that Germany was once again unified. See MARShALL DILL, JR., GERMANy, A MOdern HISTORY 441 (1961).

23. Vertrag zwischen der Bundesrepublik Deutschland und der Deutchen Demokratischen Republik über die Herstellung der Einheit Deutschlands (E inigungsvertrag), v. 28.9.1990 (B GBI. II S.889), translated in 30 I.L.M. 463 (1991) [hereinafter U nification Treaty].

24. The mass transfer of West German laws to the former GDR began with the enactment on June 21, 1990 of the Law on the Introduction of Legal Norms of the Federal Republic of Germany in the German Democratic Republic. Gesetz über die Inkraftsetzung von Rechtsvorschriften der Bundesrepublik Deutschland in der Deutschen Demokratischen Republik, v. 25.6.1990 (G BI. I S.357). See also Norbert Horn, The Lawful German Revolution: Privatization and Market Economy in a Re-unified Germany, 39 A M. J. CoMP. L. 725, 728 (1991). Not all of West Germany's laws were transferred immediately; some required a more gradual transition. For example, housing rents were raised gradually and the civil service system was transferred slowly. See id. at 729.

25. In O ctober of 1990, Germany was reunified, as the German Democratic R epublic acceded to the Federal Republic of Germany. See GG art. 23. The territory of the former GDR has been divided into five $L$ änder (states) and has been incorporated into the FRG and its federalist system through the process of accession. The five new federal $L$ änder, which encompass all of the former GDR, are Brandenburg, M ecklenburgV orpommern, Sachsen, Sachsen-A nhalt and Thüringen. See U nification Treaty art. 3-4, v. 28.9.1990 (BGBI. II at S.890), 29 I.L.M. at 464-65. The territory of East Berlin has been integrated into a state with West Berlin. Berlin itself is presently a state completely surrounded by the state of Brandenburg. A 1996 vote defeated a referendum to combine Berlin and Brandenburg into a single state, so their future status remains unclear. See K irschbaum, supra note 10 , at A 8 .

26. Vertrag über die Schaffung einer Währungs-, Wirtschafts- und Sozialunion zwischen der Bundesrepublik Deutschland und der Deutschen Demokratischen Republik, v. 25.6.1990 (B B BI. II S.537), translated in 29 I.L.M. 1120 (1990) [hereinafter Monetary Treaty]. The treaty was passed by the People's Chamber on June 21, 1990. See Horn, supra note 24 , at 728 . The GDR constitution was an obstacle to speedy unification because it embraced a centrally planned economy and socialist property rights; implementing the Monetary Treaty therefore required changes to the GDR constitution. See id. at 727. 
created a market economy for the $\mathrm{East}^{27}$ one which would "operate on principles of private ownership and competition driven by free pricing and the free movement of labor, capital, goods, and services." 28 This allowed the two Germanies to function under the same economic system. ${ }^{29}$ The M onetary Treaty also unified the currency of the GDR and FRG. The West German Mark ( $D$-M ark) became the currency of both lands while the East German currency was invalidated. ${ }^{30}$ During a legislatively-mandated transition period, East Germans could convert their currency into $D-M$ arks at very generous rates. ${ }^{31}$ Currency union and the creation of a market economy provided an economic environment in East Germany that allowed privatization to move forward.

For example, provisions of the GDR Civil Code restricted the free transfer and circulation of most property. See Zivilgesetzbuch [ZGB] CIVIL CODE §§ 17-19 (G.D.R.) (repealed in 1990). To facilitate the Monetary Treaty, the East German Parliament, in J une, 1990, adopted new "Constitutional Principles" making constitutional the principles of private ownership. See Gesetz zur Ä nderung und E rgänzung der Verfassung der DDR (Verfassungsgrundsätze), v. 22.6.1990 (G BI. I S.299) [hereinafter Constitutional Principles]. The Constitutional Principles also altered the GDR Constitution's amendment process so that future changes could be made more easily. Constitutional Principles, supra, at 300. The mass transfer of FRG laws into E ast Germany also facilitated the process. See SCHÄUBLE, supra note 20, at 177-78; supra note 24 and accompanying text.

27. Monetary Treaty art. 1(3), v. 25.6.1990 (BGBI. II at S.537), 29 I.L.M. at 1121. The program of Social Market Economy, a system in which social and economic goals co-exist, is embodied in the Guidelines to the Monetary Treaty, along with the main market principles to be implemented in the GDR. See Gemeinsames Protokoll über Leitsätze, v. 29.6.1990 (BGBI. II S.545), translated in 29 I.L.M. 1146, (1990). See Horn, supra note 24 , at $730-31$.

28. Ranier Frank, Privatization in Eastern Germany: A Comprehensive Study, 27 VAND. J. TRANSNAT'L L. 809, 818 (1994) (citing Monetary Treaty art. 1(3)). Decades earlier, a controversy existed over whether or not the Constitution of West Germany favored one economic system over another. The Federal Constitutional Court decided that the Constitution was neutral as to an economic system. See BVerfGE 4, 7 (17); BV erfGE 50, 290 (336). This decision allowed the Constitutional Court to avoid questions of economic policy. Rather, the decision allowed the policy makers to decide such issues and choose policies which they felt would best facilitate transition.

29. The economic union precipitated the need for funding in the East. The Deutsche E inheit (German U nity) fund, through which massive transfers from West to East occurred, was created to serve that need. See SCHÄUBLE, supra note 20, at 177.

30. Monetary Treaty art. 10(5), v. 25.6.1990 (BGBI. II at S.538-39), 29 I.L.M. at 1126 .

31. E ast German currency was exchangeable for D-Marks at a rate of one-to-one for basics such as wages, grants, pensions, rents, leases and personal savings. The basic currency exchange rate for some other transactions was two-to-one. See id.; HORST SIEBERT, DAS WAGNIS DER EINHEIT 21-23 (1993) (explaining the rash decision to exchange the currency and pointing out the warning signs that were ignored from the beginning). These exchange rates were very generous. See Baylis, supra note 12, at 80. 


\section{B. Privatization}

The formal process of political and economic reunification fundamentally altered the East German constitutional and legal framework, but the massive privatization process, as the cornerstone of the plan to integrate the GDR into a market economy, ultimately had the most far-reaching effects on the East German people. Like the other steps in reunification, the privatization program was conceived and implemented rapidly. Political leaders in both East and West chose to privatize East Germany completely in one step, eschewing a more gradual approach. ${ }^{32}$ Privatization involved both the sale of formerly state-owned property through the government's trust agency (the Treuhand) and the restitution of expropriated property to its rightful owners.

1. Sale of Property. The transformation to a private property system was initiated by the GDR's enactment of the Treuhandgesetz (Trust Law). ${ }^{33}$ The law created the Treuhandanstalt (Treuhand), or trust agency, to conduct privatization in East Germany. ${ }^{34}$ The first words of the Trust Law declared emphatically that privatization was to occur "as quickly and as comprehensively as possible." ${ }^{35}$ The Treuhand was to assume ownership of all state-owned enterprises and to privatize them by sale to investors. ${ }^{36}$

The transfer of ownership to the Treuhand began on July 1, 1990, the date of the Monetary Treaty. On that day, all socialist entities in $\mathrm{E}$ ast Germany became companies under German corpo-

32. See Gesetz zur Privatisierung und Reorganisation des volkseigenen Vermögens (Treuhandgesetz), v. 22.6.1990 (G BI. I S.300) [hereinafter Trust Law]. Some commentators have labeled the German approach the "Big Bang" approach; this approach is designed to have an immediate impact on the economy by transferring all state-owned enterprises to private hands as quickly as possible. See, e.g., Lan Cao, The Cat That Catches Mice: China's Challenge to the Dominant Privatization Model, 21 BRooK. J. INT'L L. 97, 99 (1995) (describing the "Big Bang" approach as the radical "shock therapy" form of privatization); Tamar Frankel, Foreword, 13 B.U. INT'L L.J. 295, 307 (1995) (describing the "Big Bang" approach to privatization as "drastic measures designed to have a strong immediate impact").

33. Trust Law, v. 22.6.1990 (GBI. I at S.300).

34. The Treuhand was created by the GDR prior to reunification and was integrated into the government of the Federal Republic in the Treaty on Unification, where it became a federal agency overseen by the minister of finance. U nification Treaty art. $25, \mathrm{v}$. 28.9.1990 (BGBI. II at S.897), 30 I.L.M. at 481.

35. Trust Law, v. 22.6.1990 (GBI. I at S.300) (author's translation).

36. See id. at S.302. 
rate law. ${ }^{37}$ The Treuhand, in turn, became the owner of all of the shares of these companies and became responsible for preparing them for sale to the private sector ${ }^{38}$ The Treuhand was required by law to evaluate the economic positions of these companies; it determined which of the former socialist enterprises were competitive enough to be privatized, which should be dismantled, and which should be liquidated. ${ }^{39}$ It was also required to evaluate prospective investors to ensure that their investment was real, would fit in with the structure of the newly reunited Germany, and would help to create jobs. ${ }^{40}$ Only then was the Treuhand authorized to sell shares and interests in the companies. ${ }^{41}$

The sale of the companies was the most important part of the privatization process. Before the Treuhand could sell interests in the formerly state-owned enterprises, it first needed reliable valuations of them. The Financial Statement $L$ aw required enterprises considered for privatization to prepare financial statements using D-M ark valuations. ${ }^{42}$ The Law also enacted measures which included an infusion of money from the Treuhand and the balancing of healthy companies with unhealthy companies to spread the little available wealth. Despite these capitalization efforts, enterprises being considered for privatization usually remained in debt. If the prospects for survival were questionable, the Treuhand decided against privatization and liquidated the company. ${ }^{43}$ If, however, the company's prospects for survival were promising, the Treuhand would fund the company up to the amount of its debt. ${ }^{44}$ The company would then be prepared for direct sale into the private sector.

The Treuhand was initially charged with the privatization of

37. See id.

38. See id.

39. See id. at S.301-02. The liquidated companies provided some of the capital needed in the transition.

40. See Martin E. Elling, Privatization in Germany: A Model For L egal and Functional Analysis, 25 VAND. J. TRANSNAT'L L. 581, 627-31 (1992).

41. See Trust Law, v. 22.6.1990 (GBI. I at S.300-01).

42. See Besondere Bestimmungen für Fortgeltendes Recht der Deutschen Demokratischen Republik, ch. III, § 1(2), v. 28.9.1990 (BGBI. II S.1173) [hereinafter Financial Statement Law]. Prior to this law, there were no reliable valuations of the state-owned enterprises, but with implementation of the Financial Statement Law, the poor financial condition of most of the enterprises became apparent. See Horn, supra note 24, at 739.

43. See Elling, supra note 40 , at $627-28$; Horn, supra note 24 , at 739.

44. See Horn, supra note 24 , at 739 . 
about 8000 firms with 40,000 plants. ${ }^{45}$ To begin the privatization process, an interested investor submitted a plan of investment. ${ }^{46}$ A mong the factors the Treuhand considered in evaluating these plans were the number of jobs created or maintained by the proposal, the "type of investment promised, the willingness and ability to remove past environmental damage, and the overall dependability and reputability of the bidder." 47 Based on this evaluation, the Treuhand decided whether or not to sell the firm to the prospective investor. ${ }^{48}$

Early in the process, interested investors often approached the Treuhand with proposals to buy. Later in the process, however, the Treuhand was forced to become more aggressive, eventually establishing offices in New Y ork and Tokyo to facilitate the solicitation of willing investors. ${ }^{49}$ As fewer willing investors were found, the Treuhand often was forced to sell at very low prices, or to close many East German companies for which no buyer could be found. ${ }^{50}$ In seeking to maximize the economic viability of privatized industries, then, the Treuhand was forced to liquidate many East German companies, ${ }^{51}$ and, consequently, many $E$ ast German jobs.

A Ithough neutral on its face, in application the Trust Law favored foreign and West German investors over E ast Germans. ${ }^{52}$ Generally, the Treuhand favored these investors because they had better access to capital than East Germans. ${ }^{53}$ Often, in fact, even

45. See horst Siebert, German Unification: The Economics of Transition 18 (The Kiel Inst. of World Econ. Working Paper No. 468, 1991). A fter the Treuhand dismantled and liquidated some firms, it was left with about 12,000 enterprises. See Romanus $O$ tte \& Wolfgang Bunse, A Gigantic Task with Mammoth Costs: German Unification, Deutsche Presse-Agentur, Sept. 2, 1995, available in LeXIS, News Library, Curnws File.

46. See Trust Law $\S 9$, v. 22.6.1990 (GBI. I S.302). For an in-depth explanation of the process that the Treuhand went through with each prospective investor before deciding whether or not to approve the application, see Fritz K. Koehler, Investment in the New German Federal States, 24 CASE W. RES. J. INT'L L. 495, 528-531 (1992).

47. Elling, supra note 40 , at 630 .

48. See id. at 630-31.

49. See id. at 628.

50. See SIEBERT, supra note 31 , at 92 .

51. See supra notes $38-41$.

52. No discrete provisions were enacted in the Trust Law to encourage East German participation in privatization or in gaining ownership in the privatized enterprises. East Germany did have some form of participation because the governments of the new federal $L$ änder were involved in the governance of the Treuhand. See Trust Law $\S 4$, v. 22.6.1990 (GBI. I at S.301).

53. See SIEBERT, supra note 31 , at 97 . Because Germany was unified, the prospects 
when East Germans did possess the capital necessary to investor, more "capable" foreign investors were favored. ${ }^{54}$ East German needs were thus subordinated in both the Trust Law's operation and effect.

2. Restitution. The other mechanism for privatization, restitution, $^{55}$ was based on the principle that property expropriated by the socialist state should be returned to its former owners. ${ }^{56}$ Wolfgang Schäuble, FRG M inister of the Interior, explained why restitution was an important issue in reunification negotiations: "It was and remains a giant task, to overcome and remedy the violations of rights of the past forty-five years, so that in the present and the future there is not great suffering from the losses, and so that old injustices do not become new injustices." ${ }^{57}$ In theory then, restitution sought to achieve a degree of parity between historic injustices and current economic needs.

In practice, restitution was a very complicated issue, due to the long history of East German expropriations and the divided views on the manner in which restitution should occur. German privatizers were forced to account for two different periods of expropriations in the history of the GDR and to decide if one or both of these eras would be the subject of the restitution policies. $^{58}$ The first wave of expropriations, from 1945 to 1949, was carried out by Soviet authorities after World War II. ${ }^{59}$ These expropriations were intended to serve both as punishment to the

for investors in East Germany appeared much more promising than did the investments in other eastern European privatizing countries. This allowed more foreign money to come into East Germany. See id. A t the same time, however, it had a detrimental effect on $E$ ast Germans, as it prevented them from investing in the newly-privatized industries. See infra notes 157-66 and accompanying text.

54. See Marshall, supra note 9 , at A 32 .

55. Restitution describes the process of returning land that was expropriated by the government of the GDR between 1945 and 1989 to its former owners. The FRG insisted on restitution-in-kind, as opposed to monetary compensation, as the cornerstone of this privatization mechanism. See infra notes 65-70 and accompanying text. For an in-depth discussion of property rights in Germany, and restitution in particular, see generally J essica Heslop \& J oel Roberto, Property Rights in the Unified Germany: A Constitutional, Comparative, and International Legal A nalysis, 11 B.U. INT'L L.J. 243 (1993).

56. See Frank, supra note 28 , at 830-31.

57. SCHÄUBLE, supra note 20 , at 260 (author's translation).

58. For a thorough explanation of the history of $E$ ast German expropriations, see Elling, supra note 40 , at $590-95$.

59. See Frank, supra note 28 , at 812-14. The government of the GDR did not come into existence until 1949, so it was not involved in this wave of expropriations. 
Nazis and as a foundation for the establishment of a communist system of property. ${ }^{60}$ The Soviet expropriations were widespread and were not accompanied by any form of compensation. ${ }^{61}$

The second wave of expropriations occurred after 1949, when the government of the GDR was created and formal Soviet control of the region ended. ${ }^{62}$ The GDR did not systematically expropriate firms as the Soviets had done; instead, the GDR took over particular businesses by applying economic pressure to force businesses into bankruptcy. ${ }^{63}$ It applied similar pressure to landowners who owed money to the government. Finally, the GDR confiscated property through criminal sentencing and other regulatory means. ${ }^{64}$

In addition to deciding which expropriation victims would be eligible for restitution, the privatizers also had to determine how to structure the compensation of former property owners. That is, the privatizers either could conduct restitution through direct monetary compensation or could implement a system of restitution-inkind, which would entail returning the land rights to former owners; on this issue, East and West German opinion differed. The East Germans opposed restitution-in-kind because it would force many people in East Germany off their land and possibly out of the homes they had occupied for the last forty-five years. ${ }^{65}$ The East Germans were particularly opposed to restitution of the land taken by the Soviets between 1945-1949 because much of that land was agricultural, was used in state farms, and was, at the time of reunification, held mainly by East Germans. ${ }^{66}$ The West Germans, however, insisted on restitution-in-kind for two main reasons. ${ }^{67}$ First, the FRG made a constitutional argument based on the takings principle in the Grundgesetz. ${ }^{68}$ The second and

60. See id.

61. See id.

62. While formal Soviet control ended for the most part in 1949, in some areas Soviet control did not disappear completely until 1954. See DILL, supra note 22, at 44.

63. See FRANK, supra note 28 , at 814.

64. See id. at 815 . Indeed, the GDR continued to expropriate property years later, by passing laws forming agricultural and trade collectives. See id.

65. See SCHÄUBLE, supra note 20, at 254-55, 258-259.

66. See id. at 260.

67. Many of the West Germans favored restitution-in-kind for the land expropriated by the Soviets as well. See id. at 259-60.

68. See GG art. 14. While negotiators from the West defended this argument, in reality it was never given much credence. See SCHÄUBLE, supra note 20, at 259-60. 
more crucial reason that the West Germans favored restitution-inkind was that they did not want the FRG to pay for the large claims that would likely result under a monetary compensation scheme. ${ }^{69}$ It was estimated that the compensation claims for all expropriated lands would amount to approximately eight billion D $M$ arks (approximately six billion U.S. dollars), a sum too large for the FRG ${ }^{70}$

The J oint D eclaration of J une 15, 1990 embodies the compromise that was reached on both issues. ${ }^{71}$ The Joint Declaration, which contains the principles of restitution, formed the basis of the law regulating all restitution claims, the $L$ aw on the Regulation of Open Questions of Property (Property Law). ${ }^{72}$ Under the Property Law, only land that was expropriated by the GDR after 1949 was eligible for restitution. ${ }^{73}$ Restitution-in-kind was selected as the method for compensation; the rightful owner of property was entitled to recover it. ${ }^{74} A$ few exceptions were provided for property held by good faith purchasers, property used for housing units, property dedicated to the public interest, and property where a joint commercial enterprise on the property would be

69. See SCHÄUBLE, supra note 20 , at $256,258-59$.

70. See id. at 256. It is important to note, however, that the West Germans have since paid about six hundred billion dollars (about nine hundred billion D-Marks) in connection with reunification, making the concern over eight billion D-M arks here seem minuscule. See infra note 150 . It seems odd that such a relatively small sum would be rejected in favor of restitution-in-kind when it would have saved many East Germans from fighting to stay on the land they had occupied for forty-five years.

71. The Joint Declaration was originally adopted by the governments of the FRG and GDR on June 15, 1990. The text was later included in the Unification Treaty. See Unification Treaty art. 41, v. 28.9.1990 (BGBI. II at S.1119), 30 I.L.M. at 496.

72. Gesetz zur Regelung offener Vermögensfragen, v. 28.9.1990 (BGBI. II S.1159) [hereinafter Property Law]. The right of restitution is now protected under article 14 of the Grundgesetz, the private property clause. GG art. 14. See also Elling, supra note 40, at $604-05$.

73. Restitution was specifically incorporated into article 143 of the Grundgesetz by the U nification Treaty. See Unification Treaty art. 4, v. 28.9.1990 (BGBI. II at 891), 29 I.L.M. at 466. Excluding property expropriated between 1945-49 from the restitution scheme was a contested constitutional issue. The Federal Constitutional Court of Germany held that the method did not contravene the Grundgesetz because the expropriations prior to 1949 were conducted by the Soviets and not the GDR. See BV erfGE 84, 90 (128-32). However, a final law on restitution, which was passed in 1995, allows victims of expropriations by the Soviet regime in the period 1945-1949 to purchase their property at current market value or receive a portion of the property itself as compensation. See Nomi Morris, No Man's Land; Across Central Europe, Millions of Victims Reclaim their Property, MACLEAN's, Sept. 25, 1995, at 24.

74. See Frank, supra note 28 , at $832 \&$ n.157. 
adversely affected. ${ }^{75}$ The rightful owners were usually awarded monetary compensation for property falling under one of these exceptions. $^{76}$

The Property Law's procedures made restitution a slow process. The Property Law required people claiming to be rightful owners of expropriated property to submit applications for their claims to certain government offices. ${ }^{77}$ Once a restitution claim was filed on a piece of property, that property could not be a part of any transaction until the claim was investigated and a decision rendered. ${ }^{78}$ Therefore, if a current holder, including the Treuhand, wanted to sell or lease property which was subject to an outstanding restitution claim, no action could be taken until a decision was rendered-which usually took months and often took years. $^{79}$

The German government also enacted the Investment Law, which worked in conjunction with the Property Law by providing exceptions to the principle of restitution. ${ }^{80}$ The Law created "a preference for the current holder of real estate over any prior holder if the real estate is required: 'to ensure or create employment . . . ;' 'to meet significant housing needs;' or 'to develop the infrastructure required' for either of the first two activities." ${ }^{81}$ $\mathrm{H}$ olders of such property could qualify for priority over restitution claimants by presenting to the local administration for examination and approval a plan outlining the potential investment plans for the property. ${ }^{82}$ Once the plan was approved, the property was certified as sound for investment purposes and was removed from

75. See Property Law § 3, v. 28.9.1990 (BGBI. II at S.1160); see also Elling, supra note 40 , at 607 .

76. See Property Law $\S \S 4-5$, v. 28.9.1990 (BGBI. II at S.1160); see also Elling, supra note 40 , at 607 .

77. The deadlines for applications for restitution of expropriated property were 0 ctober 13, 1990 and March 31, 1991. See Verordnung über die A nmeldung vermögensrechtlicher A nsprüche, v. 11.10 .1990 (BGBI. I S.2162 (S.2164)).

78. See id. at S.2164.

79. See Morris, supra note 73 , at 24 ; see also Frank, supra note 28 , at 831.

80. Gesetz über besondere Investitionen in der Deutschen Demokratishcen Republik, v. 28.9.1990 (BGBI. II S.1157) [hereinafter Investment Law].

81. Frank, supra note 28, at 835 (citing Investment Law $\S \S 1(2)(a)-(c)$ ); see Michael Gruson \& Georg F. Thoma, Investments in the Territory of the Former German Democratic Republic: A Change of Direction, in INTERnATIONAL COMMERCIAL AGREEMENTS 1992, at 455, 462 (PLI Commercial Law and Practice Course Handbook Series, No. 635 (1992)).

82. See Frank, supra note 28 , at 835 (citing Investment Law, § 1(3)). 
the purview of possible restitution claims. ${ }^{83}$ The rightful owner of the property would then receive monetary compensation instead of restitution-in-kind. ${ }^{84}$

Despite the exceptions to the Property Law embodied in the Investment Law, the possibility that former owners would assert claims against property that was to be privatized inevitably slowed investment in the new federal states. ${ }^{85}$ R estitution claims threatened to preempt investment as conflicts ensued between former owners and current holders of property. The federal government responded by amending the Property $L$ aw and the Investment $L$ aw with the Law on the R emoval of Impediments to Privatization and the Promotion of Investment (Impediments Removal Law). ${ }^{86}$ The Impediments Removal Law was passed to ease the danger of investment preemption by restitution claims and to correct the weaknesses of the Property $L$ aw and the Investment $L$ aw. ${ }^{87}$

The Impediments Removal Law focused on improving the status of investors by favoring them over restitution claimants. ${ }^{88}$ The law favored investment over restitution by creating further exceptions to the Property Law. ${ }^{89}$ It expanded the exceptions in the Investment Law which were "too narrowly defined and restrictive." 90 For example, governmental entities including the Treuhand could sell or lease property encumbered by a restitution claim, so long as the new sale was made for certain "investment purposes." ${ }^{91}$ A dditionally, a third party investor was favored over

\footnotetext{
83. See Investment Law § 2(1), v. 28.9.1990 (BGBI. II at S.1158).

84. See Investment Law § 3(4), v. 28.9.1990 (BGBI. II at S.1158).

85. See Frank, supra note 28 , at $831,840-47$; see generally Gruson \& Thoma, supra note 81 , at 455 .

86. Gesetz zur Beseitigung von Hemmnissen bei der Privatisierung von U nternehmen und zur Förderung von Investitionen, v. 28.3.1991 (BGBI. I S.766) [hereinafter Impediments Removal Law]. The amended version of the Property $L$ aw can be found at Gesetz zur Regulung offener Vermögensfragen (Vermögensgesetz), v. 26.4.1991 (BGBI. I S.958) [hereinafter A mended Property Law]. The amended version of the Investment Law can be found at Gesetz über besondere Investitionen in dem A ritkel 3 des E inigungsvertrages genannten G ebiet (Investitionsgesetz), v.26.4.1991 (BGBI. I S.995) [hereinafter A mended Investment Law]. The Investment Law was repealed in 1992. See Elling, supra note 40, at 614; see also Frank, supra note 28 , at $841-42$. See also Gruson \& Thoma, supra note 81, at 459-76 (providing an analysis of the Impediments Removal $L$ aw and its effect on investments in the former GDR).

87. See Gruson \& Thoma, supra note 81 , at 457 .

88. See Frank, supra note 28 , at 843.

89. See Elling, supra note 40 , at 611-12.

90. Frank, supra note 28 , at 841 .

91. Gruson \& Thoma, supra note 81 , at 462 . These investment purposes are similar
} 
a restitution claimant if the third party was a "more capable" investor. ${ }^{92}$ Moreover, property holders could commence investment if the plans satisfied the special purposes defined in the Investment $\mathrm{Law}^{93}$ In these circumstances, the restitution claimant could recover monetary compensation. ${ }^{94}$ Thus, in many instances, the law favored a current property holder over a restitution claimant. Finally, the Impediments R emoval Law also contained provisions designed to speed up the resolution of restitution claims. ${ }^{95}$

$E$ ven though the Impediments R emoval Law diluted the principle of restitution in order to promote investment, the results did not meet the German government's expectations. In early 1992, an estimated one hundred billion D-M arks in investment capital was still blocked by restitution claims. ${ }^{96}$ In response, in July of 1992, the government again amended the Property Law with the Investment Priority Law. ${ }^{97}$ The Investment Priority Law embodied the concept of "investment before restitution." 98 Final deadlines for restitution claims were imposed and once they had passed, all titles to real estate were deemed unencumbered. ${ }^{99}$ These procedural rules added an element of finality to the restitution process, which helped to insure the security of investments. In the Investment Priority Law, the "investment purposes" exceptions ${ }^{100}$ also were broadened to give more investors the opportunity to preempt

to the exceptions embodied in the Investment Law. See supra notes 75-76 and accompanying text.

92. See Frank, supra note 28, at 844; A mended Property Law § 3(6)-(7), v.26.4.1991 (BGBI. I at S.959-60).

93. See A mended Property Law § 3(6)-(7), v. 26.4.1991 (BGBI. I at S.959-60); supra text accompanying notes 83-84.

94. See A mended Property Law $\S 3(6)-(7)$, v. 26.4.1991 (BGBI. I at S.959-60).

95. See Frank, supra note 28, at 844-45, 847; A mended Property Law §6(a), v. 26.4.1991 (BGBI. I at S.963-64).

96. See Frank, supra note 28 , at 861 . U sing the current (J anuary 1997) exchange rate of $1.66 \mathrm{D}-\mathrm{M}$ arks to one U.S. dollar, this is equivalent to approximately sixty-seven billion dollars.

97. The Investment Priority Law is contained in A rticle 6 of the Second Property Law A mendment. Gesetz zur Ä nderung des V ermögensgesetzes und anderer V orschriften (Z weites Vermögensrechtsänderungsgesetz) art. 6, v. 21.7.1992 (BGBI. I S.1257 (S.1268)) (replacing the A mended Investment Law with the Investment Priority Law) [hereinafter Investment Priority Law].

98. Investment Priority Law $\S \S 3,4$, v. 21.7 .92 (BGBI. I at S.1269).

99. See id.; see also Frank, supra note 28 , at 861 . U nfiled claims became void and were forfeited, see id., whereas under the previous Property Law they did not. See A mended Property Law § 3, v. 26.4.1991 (BGBI. I at S.959).

100. See supra notes $81-83$ and accompanying text. 
restitution claims. ${ }^{101}$ Even after this legislation, however, by late 1992 unresolved restitution claims numbered over two million. ${ }^{102}$

\section{RESULTS OF PRIVATIZATION}

On December 31, 1994, the Treuhand officially closed its doors and the mass privatization effort in Germany came to an end. ${ }^{103}$ The effort, by many measures, was a success. When the Treuhand closed, it had transferred almost all of its enterprises to the private sector. The Treuhand sold 6500 companies to private investors, reprivatized 1600 , sold 300 to local communities, and shut down about $3700 .^{104}$ By December 31, 1994 only sixty companies remained unsold. ${ }^{105} \mathrm{Nearly}$ half of the companies the Treuhand gained ownership of in 1990 are still in business today as private entities. ${ }^{106}$

Traditional economic measures, like the growth rate and GDP of East Germany, also indicate the Treuhand's success. With an annual growth rate that reached over nine percent in late 1995, East Germany has become one of the most quickly expanding regions in Eastern Europe. ${ }^{107}$ Over the last five years, the per capita GDP of E ast Germany has increased from thirty percent of the per capita GDP in the West to fifty percent. ${ }^{108}$ While GDP for all of Germany fluctuated from 1990 to $1995,{ }^{109}$ it is expected to have grown one percent in 1996 and two percent in $1997 .{ }^{110}$ This growth rate appears low; however, since West Germany absorbed the dilapidated state economy of the East, such numbers are viewed by most as evidence of success. ${ }^{111}$

Indeed, given the tumultuous and difficult political context in which the German project took place-the collapse of Eastern Europe and a worldwide recession-the economic numbers are

101. See Investment Priority Law $\S \S 3,4$, v. 21.7 .92 (BGBI. I at S.1259).

102. See Frank, supra note 28 , at 862 .

103. See Eisenhammer, supra note 5 , at 36 .

104. See 0 tte \& Bunse, supra note 45 .

105. See E isenhammer, supra note 5 , at 7 .

106. See Walsh, supra note 6 , at 1 .

107. See 0 tte \& Bunse, supra note 45 .

108. See id.

109. See supra note 7; Hilfe Country Report, Germany, Janet Matthews Info. Serv.

(Sept. 1996), available in LEXIS, World Library, Profil File.

110. See Hilfe Country Report, supra note 109.

111. See supra note 4 and accompanying text. 
impressive. Political pressure was immense, and the Germans were confronted with previously unencountered mass privatization and reunification. West Germany transferred an enormous amount of funds to the East and constructed a legal regime which successfully privatized and incorporated an entire economy. In the face of these challenges, the relatively smooth transition is remarkable.

This success, however, has not been without social and economic costs. While privatizers abstractly recognized the turmoil the East German people would face throughout the transition and made limited attempts to smooth the process, a number of concrete problems remain. These problems collectively concern the long-term integration of E ast German society into the new Germany. A s one commentator has stated:

[T] he unification of the two German states had . . . far-reaching consequences for the former GDR and its citizens. The sudden dissolution of a state with its social and economic order, together with the attempt to bring about a fast and comprehensive reorganization of important social functions based largely on the western model [left] ... every individual citizen ... confronted with the changes in cultural and political values induced by the unification process, or with reorienting and adapting his or her behavior to these changes. ${ }^{112}$

Sociological studies have suggested that "East Germans lack the life skills and strategic thinking needed to build careers, establish firms, or just make a decent living in a highly individualized society." 113 The lack of preparation and instruction for entry into a market economy has left East Germans uninformed about and uninvolved in their new economy. ${ }^{114}$

East Germans, in turn, have reacted to privatization with

112. Detlef Landua, The Social Aspects of German Unification, in THE Economics OF German UNIFICATION 92, 92 (A. Ghane Ghaussy \& Wolf Schäfer eds., 1993).

113. Feiwel Kupferberg, Managing an Unmasterable Past, SoCIETY, Jan.-Feb. 1996, at 69, 71.

114. See Baylis, supra note 12 , at 81 ; K upferberg, supra note 113 , at 71 . M any East Germans did not understand how their new economy functioned. For example, one East German car company possessed back orders for cars (Trabbis, the only car widely-available in East Germany prior to reunification) for fifteen years under the GDR. A fter reunification, however, as other options emerged, no one wanted to buy them. The company's leaders did not realize that they should stop manufacturing because there was no demand for their product. East German businesses were simply not prepared for the entirely new way of thinking and functioning. See Yuri Shpakov, How She Sold the GDR: Interview with Birgit Breuel, Moscow NEWS, June 24, 1994, at 23. 
feelings of disbelief and betrayal. M any $\mathrm{E}$ ast $\mathrm{G}$ ermans believe that the Treuhand sold off property as quickly as it could, paying little attention to the effect it would have on life in East Germany. ${ }^{115}$ In surveys conducted in 1990, E ast Germans were markedly less satisfied than West Germans with their quality of life. ${ }^{116}$ Beginning in 1991, monthly surveys tracked the massive discontent in East Germany, ${ }^{117}$ as seventy to eighty percent of East Germans consistently stated that they were unsatisfied with reunification. ${ }^{118}$ Graffiti on E ast German walls reads "Verraten und Verkauft""Betrayed and Sold." 119 Playwright Rolf Hochhuth criticized the Treuhand and its "plundering" of East Germany in his play "Wessis in Weimar: Scenes from an Occupied Land." 120 The play delves into the East Germans' feelings of anger and frustration caused by the Treuhand's policies. ${ }^{121}$

Disillusionment with the transformation process and the unified government persists, ${ }^{122}$ as recent election results demonstrate. In 1994 elections, some East Germans voted for the former communist party, expressing their dissatisfaction with the new market system. ${ }^{123}$ In the 1995 Berlin elections, the Partei des demokratischen Sozialismus (Party of D emocratic Socialism (PDS)), successor to the GDR's communist party, the Sozialistische Einheitspartei (Socialist U nity Party (SED)), captured thirty-six percent of the vote in the eastern half of the city. ${ }^{124} \mathrm{M}$ ore recent-

115. See Heslop \& Roberto, supra note 55, at 293.

116. See Landua, supra note 112 , at 99-102.

117. See Keuchler, supra note 19, at 33, 46. For a collection of discussions concerning the psychological impact of unification on both East and West Germans, see generally Psychologische Aspekte des Sozio-Politischen Wandels in Ostdeutschland (G isela Trommsdorff ed., 1993).

118. See Kuechler, supra note 19 , at 47.

119. See Heslop \& Roberto, supra note 55, at 293.

120. Rolf Hochhuth, Wessis in Weimar: Szenen aus einem besetzen land (1993). The play opened in Berlin in 1993 and was criticized by German politicians as sanctioning violence against the government and the Treuhand to appease East German feelings. See Michael Lawton, Well-Schooled in Scandal, TIMES (London), June 10, 1992, $\S 2$ (Life \& Times), at 5 .

121. See generally HOCHнUTH, supra note 120 .

122. See, e.g., Jurgen Habermas, Struggles for Recognition in the Democratic Constitutional State, in MULTICULTURALISM 107, 147 (A my Gutmann ed., 1994) (discussing the "smoldering resentments" of the East Germans in response to reunification and a perceived lack of representation in the politics of the reunited Germany).

123. See Hasenkamp, supra note 8 , at 9 .

124. See Mortimer, supra note 4, at 7. The SED, the communist party in the former GDR, dominated the government. People were forced to become members of the SED 
ly, in 1996 voters in East Berlin and Brandenburg voted not to join together to become a single state. ${ }^{125} \mathrm{~V}$ oters cited their mistrust of federal government officials, who they felt had failed to keep their promises, and the persistent, deep divide between East and West Germans as reasons for the vote. ${ }^{126}$ O pinion polls also demonstrate popular disillusionment. They consistently show that East Germans are less dedicated to a liberal democratic system, both politically and as a lifestyle, than are W est Germans. ${ }^{127}$

The slow integration of the two Germanies may be traced to the privatizers' failure to focus on the distributional consequences of privatization. The three most significant problems associated with German privatization are: high unemployment; the nature of restitution and its consequences; and the lack of East German ownership in the newly privatized enterprises. The combination of these factors has resulted in an economic and social divide between East and West that threatens the political stability of a reunified Germany. ${ }^{128}$

and follow its ideology in order to gain employment or educational opportunities in the former GDR. See TURNER, supra note 18, at 47.

125. See Kirschbaum, supra note 10 , at A 8 .

126. See id.

127. See Kupferberg, supra note 113 , at 70 .

128. Some political philosophers have developed theories that account for the general "social well-being" concerns highlighted in East German privatization. Professor Cass Sunstein has suggested that democratic governments should measure social well-being as well as GDP in determining the success of government policies because "[a] high priority for those thinking about the role of the state should be to develop methods for focusing attention on things that matter to people's lives." Cass R. Sunstein, Well-Being and the State, 107 HARV. L. REV. 1303, 1304 (1994). Sunstein's definition of social well-being includes factors such as life expectancy, educational opportunities, access to political power, self-respect, the availability of social goods, see id. at 1309-10, access to health services and safe water, the number of radios and televisions in a country, the nature of relations with other people in the local community, see id. at 1321-23, "housing, security of life and property (including freedom from crime), availability of recreational and cultural resources, employment, income and wealth, and political participation." Id. at 1322.

J ohn Rawls similarly suggests that an adequate measure of well-being also include measures of "a. basic rights and liberties . . . ; b. freedom of movement and free choice of occupation against a background of diverse opportunities; c. powers and prerogatives of offices and positions of responsibility in the political and economic institutions of the basic structure; $d$. income and wealth; and finally, e. the social bases of self-respect." John Rawls, Political Liberalism 181 (1993).

Germans Walter Eucken and Ludwig Erhard proposed similar theories decades ago. See Alan Peacock \& Hans Willgerodt, German Liberalism and Economic Revival, in Germany's SOCIAL Market ECONOMY: ORIgins and EVolution 1, 1-10 (A Ian Peacock $\& H$ ans Willgerodt eds., 1989). These theories inhere in the idea of a social market economy. For an in-depth look at the German social market economy, see generally 


\section{A. Unemployment}

The E ast Germans have had to contend with the seemingly intractable problem of unemployment. ${ }^{129}$ At the time of reunification, 9.7 million people were employed in the former GDR; by 1994, the number had fallen to 6.2 million. ${ }^{130}$ Nearly half of the working age population in East Germany was put out of work in the transition, ${ }^{131}$ burdening the Treuhand with the label "Job Killer Number One." ${ }^{132} \mathrm{~N}$ ot even one-third of E ast German employees retained the jobs they possessed at reunification by early 1995. ${ }^{133}$ The unemployment picture remains bleak, as the 1995 unemployment rate in East Germany was 13 percent. ${ }^{134}$ In the East German town of D essau in O ctober, 1996, the unemployment rate was 20.1 percent, excluding those who had been given early retirement and those who were participating in government training programs. ${ }^{135}$ In Germany as a whole the unemployment rate in 1995 was 9.4 percent and was expected to rise to 10.3 percent

Germany's Social Market Economy: Origins and Evolution, supra. While a complex theoretical framework in which to evaluate privatization decisions is beyond the scope of this Note, it is significant that such a theory may provide a better or, at least, alternative way in which to measure the success of a project such as mass privatization.

129. Critics point out that the situation previously in the GDR was one of "overemployment." See Landua, supra note 112, at 93-94. While critics suggest that communist overemployment made unemployment a necessity in the transformation to a market economy, that attitude fails to acknowledge the psychological and social effects that result from unemployment-a fortiori the unexpected overnight unemployment associated with East German political upheaval.

130. See Eisenhammer, supra note 5, at 7. While unemployment was a difficulty for many, others suffered the fate of shortened working hours. See Reus, supra note 4, at 21. The figures for unemployment do not include numbers for those whose working hours have been reduced.

131. See Walsh, supra note 6 , at 1 .

132. Ramesh Jaura, Germany-E conomy: Crucial Privatization A gency Gets Mixed Reaction, Inter Press Serv. (J an. 5, 1995), available in LEXIS, World Library, A llwld File.

133. See id.

134. See Hasenkamp, supra note 8 , at 9 . This $13 \%$ unemployment rate does not indicate the true number of people out of work. In East Germany, many people, mostly women who were fully employed under communism, have dropped off the unemployment register and are now receiving welfare. Also, many people are in job creation schemes and are actually not working. These schemes are beginning to be cut for lack of funds, and the people in these job creation schemes are not counted in the unemployment statistics. See Judy Dempsey, No Work, Little to Believe in: Popular Pressure for Politicians to Find Solutions to East German Unemployment, FIN. TIMES, Jan. 28, 1994, at 17.

135. See Alan Cowell, Kohl is an Iron Man, But the Price is High, N.Y. TIMES, Oct. 30, 1996, at $A 1$. 
in $1996 .{ }^{136}$ The German Confederation of Trade U nions predicts that in the year 2000 there still will be one million jobless people in East Germany and that the employment level will remain below that of 1992 until at least 2003. ${ }^{137}$

U nemployment in East Germany was caused mainly by two aspects of the unification process: ${ }^{138}$ the implementation of a currency union under the Monetary Treaty and the privatization undertaken by the Treuhand. When the currency union took place in 1990, ${ }^{139}$ East Germany suddenly was thrown into competition "virtually unprotected, .... with one of the most efficient and technologically advanced western economies [W est Germany's]-as well as with the economies of the Federal Republic's partners in the European Union, Japan, and other wealthy capitalist states." 140 East German workers' wages rose quickly, increasing by fifty-three percent from reunification to 1994, thus eliminating the competitive advantage possessed by E ast Germany in cheaper labor. ${ }^{141}$ The result of exchanging $E$ ast German $M$ arks and D $M$ arks at a 1:1 ratio was that the price of $E$ ast $G$ erman enterprises rose by about 400 percent, making investment much less attractive. ${ }^{142}$ This overvaluation of the $E$ ast German Mark had di-

136. See Hilfe Country Report, Germany, supra note 109.

137. See Jaura, supra note 132.

138. Of course, unemployment was an inevitable result of the shift from a socialist economy to a market economy. Nonetheless, the methods the German privatizers used to prepare the citizens for this massive unemployment were inadequate. See infra notes 146-50 and accompanying text. While a European recession was occurring at the same time as privatization and high unemployment was common throughout western Europe, East Germany was unique in that its unemployment rate jumped from full employment in 1989-90, under socialism, to massive unemployment the following year. See supra notes 129-37 and accompanying text.

139. Politics affected decisions about currency unification. A s E ast Germans witnessed what was available in the West they applied election pressure to $\mathrm{Kohl}$ and his government. See Bernstein, supra note 14 , at 6 . Two other reasons for the currency union were to stop migration from eastern to western Germany and to facilitate the unification process. See Horn, supra note 24 , at 733 . The German government had attempted to use currency union to help the East Germans, but it was a disaster for the economy. East Germans were completely unprepared for the ensuing unemployment. See Baylis, supra note 12 , at 81 .

140. Baylis, supra note 12, at 80; see also VINCENT EDWARDS \& PETER LAWRENCE, MAnAgEment Change IN EASt GERMAnY 1, 3 (1994) (outlining various economic difficulties suffered by the former GDR following currency union).

141. See Eisenhammer, supra note 5, at 7; SIEBERT, supra note 31, at 126-27. While the wages that $E$ ast $G$ ermans were receiving under the Communist regime sufficed for consumption in the GDR, once more expensive western goods were available, the East Germans demanded higher wages to compensate. See Bernstein, supra note 14, at 6 .

142. See Shpakov, supra note 114, at 23 (reporting interview with Birgit Breuel, Presi- 
sastrous effects on the East German economy. A s wages in East Germany increased to account for the overvaluation, E ast German companies were forced to demand higher prices. Higher prices then led to decreased trade; trade with eastern European countries, formerly East Germany's largest trading partners, declined dramatically. ${ }^{143}$ In 1991, productivity in the East was thirty percent of that in the West. ${ }^{144}$ Climbing wages, combined with decreased productivity, led to the high levels of unemployment. ${ }^{145}$

U nemployment is especially problematic because East Germans were unprepared for the massive displacement that followed reunification. Before 1990, East Germany had little experience with unemployment; under the former socialist regime, full employment was the priority, even if it meant inefficiency. ${ }^{146}$ Chancellor Helmut Kohl promised the East Germans "blossoming landscapes" with reunification, and failed to warn them of the hard times to come. ${ }^{147}$ Predictions in the Treuhand's early days were that privatization would end with "the agency's coffers overflowing with profits." 148 The politicians shared these optimistic predictions with the German people, making matters worse by failing to prepare them for the difficulties associated with the reunification process. ${ }^{149}$ Instead of ending its process with "overflowing coffers," however, the Treuhand lost about 200 billion dollars in its five years of existence, money which German taxpayers will have to repay. ${ }^{150}$ The next generation will be paying to rebuild East Ger-

dent of the Treuhand). A nother commentator has estimated that the price rose even more-by $500 \%$. Hasenkamp, supra note 8 , at 9 .

143. See Baylis, supra note 12 , at 83 .

144. See SIEBERT, supra note 31 , at 40.

145. See id. at 128. See also Klaus-D ieter Schmidt \& Birgit Sander, Wages, Productivity and Employment in Eastern Germany, in THE ECONOMICS OF GERMAN UNIFICATION, supra note 112, at 60-65 (arguing that more modest growth of wages would have helped to preserve old jobs at least in the short term). This unemployment cannot be blamed solely on the German government. East German workers, labor unions and some East German managers demanded higher wages and kept productivity low, contributing to the problem of unemployment. See SIEBERT, supra note 31, at 125.

146. See Landua, supra note 112 , at $93-94$; see also Baylis, supra note 12 , at 81 .

147. Cowell, supra note 131, at A 1; see also K upferberg, supra note 116, at 75 (explaining that East Germans' "lack of familiarity with democratic politics" led them to "firmly believe the promises of Chancellor Kohl").

148. E isenhammer, supra note 5 , at 36 .

149. See Cowell, supra note 135 , at A 1 .

150. See Hasenkamp, supra note 8 , at 9. More money from West Germany was not the answer either, as the west more than generously subsidized the privatization process. West Germany transferred over 400 billion dollars to East Germany in the first 5 years 
many well into the future, as a debt of 340 billion D-M arks from the former GDR still exists. A s of September, 1995, West Germany still transferred more than five percent of its GNP to East Germany. ${ }^{151}$

East Germans blamed the Treuhand for their problems. ${ }^{152}$ For them, "[t]he Treuhand became a symbol of the brute force of capitalism." 153 The Institute for Labor Market Research published a study emphasizing the "enormous adjustment burdens" faced by unemployed East Germans. ${ }^{154}$ East Germans would rather work than receive federal money, but jobs have been unavailable since privatization. ${ }^{155}$ The inevitable psychological damage from the transition only makes long-term social integration more difficult. ${ }^{156}$

Second, unemployment was caused by the privatization process itself. The Monetary Treaty and the currency union caused a shock to the economy and made the Treuhand's task even more difficult. The goal of the government was to privatize as quickly as possible. ${ }^{157}$ The Treuhand, in facing the task of privatization, dis-

after reunification. See 0 tte $\&$ Bunse, supra note 45 , at $* 4$. The total was 600 billion dollars by the fall of 1996, leaving West Germans with higher tax burdens equally unsatisfied. See Cowell, supra note 135, at A 1. Early estimates for payments through the Deutsche Einheit fund were greatly underrated which only fueled the discontent among West Germans. See SCHÄUBLE, supra note 20 , at $178-79$. See also SIEBERT, supra note 31 , at 146-73.

151. See 0 tte \& Bunse, supra note 45 , at $* 3$. These transfers to $E$ ast $G$ ermany will not end any time in the near future. One agency estimated that such transfers will remain a "serious drain" on public finances in Germany for at least the next fifteen years. Hilfe Country Report, Germany, supra note 109 , at $* 17$. See generally Wilhelm Bleek, Der Umbruch in der DDR und wir in der Bundesrepublik, in EINE DEUTSCHE REVOLUTION 60, 60-79 (Gert Joachim Glaeßner ed., 1991) (explaining the social issues and difficulties faced by the West Germans in adjusting to unification).

152. Detlev Rohwedder, the first head of the Treuhand, was assassinated in 1991 by the Red A rmy Faction. The Red A rmy Faction is a radical group in Germany that protested the treatment of East Germans by the unified German government, especially by the Treuhand. See Koehler, supra note 46, at 514-515 n.77 (explaining the Red A rmy Faction's criticism and protest of Treuhand). The Red A rmy Faction began in the 1960s in the Federal Republic of Germany. The group grew out of the student protest movement in the political aftermath of World War II. See JOANNE WRIGHT, TERRORIST PROPAGANDA 23-27 (1990). The Red A rmy Faction, which calls itself a "communist revolutionary group working to overthrow the West German state," uses violence and propaganda to further its cause. See id. at xii-xiii.

153. See Eisenhammer, supra note 5 , at 36 .

154. Jaura, supra note 132.

155. See Dempsey, supra note 134 , at 17 .

156. See id.

157. See Trust Law, v. 22.6.1990 (BGBI. I S.300); see also supra note 35 and accom- 
assembled many enterprises and cut out the overemployment typical of the communist system, which led to high unemployment rates and disenchantment with the new market system. ${ }^{158}$ Low levels of investment often forced the Treuhand to attract investors by selling property below market value, by assuming debts and operating losses of the enterprises it was attempting to privatize, and by paying for environmental cleanup. ${ }^{159}$ Much of this activity led to further unemployment. ${ }^{160}$ In the first few years of privatization, industrial production in the former GDR fell by twothirds, causing unemployment. ${ }^{161}$ In short, the Treuhand "caused excessive economic dislocation for eastern Germans." ${ }^{162}$

A Ithough it was necessary to eliminate overemployment, the speed with which privatization occurred, combined with the lack of preparation, created massive economic dislocation. The dramatic increase in wage levels caused by the currency union necessitated unemployment because businesses found the new wages unaffordable. ${ }^{163} \mathrm{~A}$ better strategy would have been "to subsidise unnecessary jobs temporarily [rather] than to support large numbers of unemployed in east Germany." 164 The generous unemployment compensation provided by post-unification Germany could alternatively have been utilized to subsidize wages; ${ }^{165}$ easing people out of employment more gradually would have allowed more time for adjustment. Also, warning the East Germans in advance would have helped them to prepare.

panying text.

158. See, e.g., Hasenkamp, supra note 8, at 9; Kupferberg, supra note 113, at 75-77.

159. See Eisenhammer, supra note 5 , at 7 .

160. See id.; see also SIEBERT, supra note 31, at 102 (explaining that because the Treuhand had no information and no market to measure the value of the enterprises, it was often forced to take what it could get for the enterprises, which usually meant selling them very cheaply). See Hasenkamp, supra note 8 , at 9 (discussing high level of unemployment, which is surprising to those who had become accustomed to Communist guarantees of employment for life); VAN DER VAT, supra note 13, at 258 (stating that Treuhand "rationalized... jobs out of existence in order to rid itself of otherwise unsaleable assets").

161. See Baylis, supra note 12 , at 83 .

162. Hasenkamp, supra note 8 , at 9 .

163. See Schmidt \& Sander, supra note 145 , at 66 .

164. Dempsey, supra note 134 , at 17.

165. See Schmidt \& Sander, supra note 145 , at 66-71. 
B. The Nature of Restitution

A s of September, 1995, of the 2.7 million restitution claims that had been filed, only about one-third had been decided. ${ }^{166}$ The process chosen for restitution, which favored restitution-inkind, was criticized from the outset because of the fact that it would discourage investment. ${ }^{167} \mathrm{As}$ a result of compensating restitution claimants in kind, even with the multitude of pro-investment laws enacted by the German government, restitution has remained a slow and painful process. ${ }^{168}$ As one restitution claimant stated, "[t]he Wall is gone, but the victims remain." 169 The backlog of restitution claims still causes complaints among the population and is a serious problem facing the German polity today. ${ }^{170}$ If Germany had chosen to provide restitution by monetary compensation, rather than in kind, many of today's problems could have been avoided. ${ }^{171}$

The nature of the chosen restitution policies-often pitting claimants from the West against current holders of property from the East-has only increased animosity between West and East Germany. R estitution-in-kind, by definition, transferred ownership of East German property out of the hands of E ast Germans and into those of former owners, who were usually either foreigners or, more often, West Germans. ${ }^{172}$ This process naturally caused resentment on the part of $\mathrm{E}$ ast Germans towards their Western counterparts, further exacerbating the sense of division between East and West. A policy which favored monetary compensation could have avoided much of the hostility inherent in the restitution process: direct monetary restitution would have compensated the former owners for the injustices they suffered, but would have allowed physical possession and ownership of the property and enterprises to remain in the hands of $E$ ast German citizens. $\mathrm{H}$ owever, the process of restitution-in-kind has only emphasized the

166. See Morris, supra note 73 , at 24 .

167. See Horn, supra note 24 , at $742-43$.

168. See SIEBERT, supra note 31, at 65-66 (questioning whether restitution was the proper principle to follow in privatization); see also supra notes 96-102 and accompanying text.

169. Morris, supra note 73 , at 24 .

170. See id.

171. For discussion of the Czech system of restitution, see infra notes 198-208 and accompanying text.

172. See Morris, supra note 73 , at 24 ; infra notes $174-76,180$ and accompanying text. 
differences between $\mathrm{E}$ ast and West Germans and has become another roadblock to true integration.

\section{Lack of O wnership}

E ast Germans have been left with very little ownership in what was their country. ${ }^{173}$ Throughout the process of transferring ownership of state-owned enterprises into private hands, the Treuhand concentrated its sales efforts on West Germans and foreigners. ${ }^{174} \mathrm{~V}$ ery few East Germans had the capital to participate in the privatization process, so the Treuhand sought out as many foreign and West German investors as possible in order to retain Germany's place in the world market. ${ }^{175}$ East Germans were often rejected as investors even if they possessed the capital to invest. The Treuhand rejected their offers by saying the plans were "economically backward" compared to Western, "forwardlooking" plans. ${ }^{176}$ West Germans and foreigners were also favored because East Germans were not trusted to make intelligent and profitable investments. ${ }^{177}$ As a result, East Germans were left largely with no ownership in their country. A s Otto Schilly, a federal parliament member, said,

The problem is that Treuhand degraded east Germans as objects rather than subjects of the process. They should have been more highly integrated. . . . East Germans have lost faith in the transformation process. We forgot that a market economy is also determined by psychological factors. "Corporate identity" is

173. It is important to note that Germans do not traditionally invest in stocks. See Can Germans O vercome Their Fear of Equities?, Bus. WK., Oct. 23, 1995, at 16; M ichael R. Sesit \& G reg Steinmetz, Telekom Workers to Reap Stock Windfall, WA LL ST. J., Dec. 14,1995 , at C1. However, this is not directly relevant to the East German situation. It is West Germans who have traditionally not held stock; the East Germans, who lived in a socialist economy, have not had the opportunity to own stock for the last 45 years. By recognizing the differences between East and West Germans in this way, perhaps the East Germans could become more involved, or at least have a stake in their economy with some form of ownership. Beyond stock ownership, however, the companies that were sold were sold almost exclusively to private parties, and most of those parties were West Germans or foreigners, not East Germans. See Shpakov, supra notes 114, at 23.

174. See Shpakov, supra note 114, at 23 (describing the Treuhand's desire for foreign investors and investors familiar with "modern management techniques" and capable of providing "production . . . technologies.").

175. See id.

176. Hasenkamp, supra note 8 , at 11 .

177. See Marshall, supra note 9 , at $\mathrm{A} 32$. 
something that is now missing in east Germany. ${ }^{178}$

So much investment in the East came from West Germany that, today, "eastern Germany is quite literally becoming an economic colony of West German capital." 179

The privatization process set up by the German privatizers excluded East Germans from participation; a "colony" of West Germany has resulted. East Germans have no stake in their economy; many do not understand how it works and have become bitter about outsiders' participation in the privatization process. A s one commentator stated:

The most disturbing effect of ... [privatization] is the bitter feeling on the part of many eastern Germans that their once-national property has been sold off to outsiders-to western Germans, mostly-and that the easterners who kept the economy plodding along all those difficult years under communism didn't have the wherewithal to enter the bidding fray. ${ }^{180}$

This exclusion has contributed to the general discontent exhibited in East Germany which, in turn, has led to political turmoil and a low level of commitment to the market economy. Jobs have disappeared, the East Germans have virtually no ownership in their former country, and because the East G ermans were not prepared for the shock of a new economic system, the morale and attitudes of the people are almost beyond repair. ${ }^{181}$ Critics say that the psychological scars displayed by the East Germans are "so deep ... . that they have put the east into a worse position-for all its newfound economic potential-than Eastern Europe's other former Communist states." 182

The enormous task of creating true political, social, and economic integration of the two Germanies required a structurally different privatization process. ${ }^{183}$ Policymakers today can learn

178. Hasenkamp, supra note 8 , at 11 .

179. Baylis, supra note 12 , at 86 . See also Edmund L. A ndrews, Bonn's Bank Buys Hollow E conomy, N.Y. TIMES, A pril 17, 1997, at A 1. Not only is East Germany becoming an economic colony, but it has similarities to a political colony as well. Even in eastern Germany, West Germans occupy most of the high political positions. See Detlef Schubert, Between Gain in Prosperity and Loss of Competence: Reflections on the Social and Political Situation of the East German People after German Unification, in GERMAN MONITOR, RE-A SSESSING THE GDR 31, 38-45 (J.H. Reid ed., 1994).

180. Walsh, supra note 6 , at 1 .

181. See Dempsey, supra note 134 , at 17 .

182. Walsh, supra note 6 , at 1 .

183. See Gert-Joachim Glaeßner, Vorwort, in EIne Deutsche Revolution, supra 
from the successes and failures of the German privatization program, from its failure to focus on the distributional consequences of privatization and the resulting lag in achieving the goal of longterm integration, as well as by comparing German privatization to alternative methods.

\section{Alternative Methods of Privatization}

A Iternative methods of privatization may help fill in the gaps in the German privatization model and guide today's privatizers to methods better tailored to fit their needs. Germany's post-privatization problems should serve as warning signs to today's privatizers to avoid similar results; privatization will be successful only where people accept, understand, and participate in the resulting market economy and where political stability thereby remains. While every country is unique and no comparison will be exact, every privatization involves the same fundamental process: the transfer of ownership from the state to private hands. This discussion will focus on privatizations in two very different contexts, which together highlight the most important deficiencies in the German model: the former Czechoslovakia, on the one hand; and Latin A merica and Southeast A sia, on the other. While lessons from the Czechoslovak privatization program involve what was done right in that effort, the lessons from Southeast A sia and Latin A merica involve what was done wrong.

note 151 , at $5,7-8$.

The reunification of the two German states also meant that two German societies, which were completely different from one another, with completely different individual and collective experiences, who knew almost nothing about the other, were forced into one society. . . . Fundamental differences in social characteristics existed which cannot be assimilated to one another by laws or with the help of the German National Bank. ... The walls of stone and cement have fallen, but the walls in the heads of the people still remain.

Id. at 5, 7 (author's translation). 


\section{A. The Former Czechoslovakia}

The former Czechoslovakia, ${ }^{184}$ like E ast Germany, undertook a program of simultaneous democratization and mass privatization in the early 1990s. At the beginning of the privatization process, the Czechoslovak economy was technically backward and suffered from a low rate of productivity. ${ }^{185}$ Like the East German economy, it was dominated by state-owned enterprises, which accounted for ninety-eight percent of Czechoslovakia's GDP. ${ }^{186}$ B ut Czechoslovakia was forced to conduct privatization through different mechanisms than Germany, ${ }^{187}$ and as a result, it successfully transformed its economy and government while avoiding the "colonial mentality" that has developed in East Germany. ${ }^{188}$ The legal structure of privatization in the Czechoslovakia better served the goal of involving its citizens in the new economy by providing them with opportunities for influence and participation in that economy. This Note focuses on three aspects of Czechoslovak privatization: preparation, restitution, and direct sales and voucher privatization.

184. Czechoslovakia had been a unified country since 1918, when the Czech Republic and Slovakia were combined as a single federation. The distinct cultures and economies of the two co-existed for decades, but privatization and a transition to democracy complicated this co-existence; on January 1, 1993, the federation broke up and the Czech Republic and Slovakia were reformed. Currently, the Czech Republic continues the privatization process begun under the Czechoslovakian federation. A lthough a comprehensive study of privatization in the former Czechoslovakia is beyond the scope of this Note, the privatization which began in a unified Czechoslovakia is relevant: the characteristics most salient to the German model will be the focus here. For an in-depth analysis of Czech privatization, see, for example, Roman Frydman, et al., The Privatization Process in Central Europe 40-95 (1993); Michele Balfour \& Cameron Crise, A Privatization Test: The Czech Republic, Slovakia, and Poland, 17 FordHAM INT'L L.J. 84 (1993); A nna Gelpern, The $L$ aws and Politics of Reprivatization in East-Central Europe: A Comparison, 14 U. PA. J. INT'L BUS. L. 315 (1993).

185. See Michael Mejstrík \& Milan Sojka, Privatization and Regulatory Change: The Case of Czechoslovakia, in Privatization and Regulatory Change IN EuROPE 66, 66 (M ichael Moran \& Tony Prosser eds., 1994) (describing Czechoslovakia's economic crisis).

186. See id. at 68.

187. See id. Because Czechoslovakia was not absorbed into a rich western country, it was forced to conduct privatization in a manner which required citizen participation and little capital, because its citizens possessed little, with supplements from foreign investment. See id.

188. Walsh, supra note 6 , at 1 . 
1. Preparation. The first important lesson from Czechoslovakia is that "rhetoric and reality must strike a balance." ${ }^{189}$ The citizens of the Czechoslovakia were warned in advance that privatization would be a difficult process. ${ }^{190}$ The citizens seem to have accepted that and complained little about the economic difficulties. ${ }^{191}$ Because Czechoslovak leaders warned citizens in the beginning that the transformation would be difficult, the citizens have been pleasantly surprised. ${ }^{192}$ By maintaining realistic expectations, the Czechoslovak government helped its citizens to prepare psychologically for the massive transformation to come. These warnings allowed citizens of Czechoslovakia to retain "a psychological advantage over E ast G erman[s]." 193

The East Germans were led to believe that privatization would bring immediate prosperity. ${ }^{194}$ They have received much greater subsidies than did the citizens of Czechoslovakia, but "their expectations were raised too high at reunification, leaving disappointment in its wake." ${ }^{195} \mathrm{H}$ igh expectations are one reason that unemployment has had such a dispiriting impact on East Germans. In Czechoslovakia unemployment was expected, but in East Germany it was not. The reality of the situation has bred general discontent among East Germans and has begun to lead to political instability. ${ }^{196}$ While in Germany there is little danger of the democracy or economy failing, ${ }^{197}$ other privatizating nations may be more susceptible to political and economic instability. Informing the polity will combat instability.

189. See Susan Greenberg, Czechs get Reform Balance Right; Tempering Rhetoric with Realism is Proving a Success, GUARDIAN (London), Feb. 26, 1994, at 33.

190. Id.

191. See id.

192. See id.

193. Id.

194. See supra notes $147-51$ and accompanying text.

195. G reenberg, supra note 189 , at 33 .

196. See supra notes $119-26$ and accompanying text.

197. East Germany has a great advantage over most privatizing nations in that it immediately joined West Germany, a stable democratic country with a market economy. Because West Germany is such a strong country, the problems which may severely effect the precarious economic balance in other Eastern European and developing countries will not likely have the effect on Germany of destroying the market economy or democracy. 
2. Restitution. The Czechoslovak leaders, like their German counterparts, chose to return property expropriated under communism to its rightful owners in order establish a base for a market economy with private property rights. ${ }^{198}$ Czechoslovakia passed two restitution laws in the fall of 1990. These laws embody the Czechoslovak attempt to restore ownership of assets, such as real estate and enterprises that were taken in the latest wave of communist expropriations, beginning in 1948. ${ }^{199}$ The Czechoslovak restitution scheme is the largest being carried out in Eastern E urope, outside of that in the former GDR. ${ }^{200}$

Czechoslovakia feared that its citizens might encounter the same problems Germans had faced, such as the slowdown of investment due to complications in the purchase of land subject to restitution claims. ${ }^{201} \mathrm{As}$ in Germany, restitution-in-kind was the preferred form of restitution. When that was impossible, compensation, usually in the form of low-interest bonds, was provided. ${ }^{202}$ The Czechoslovak privatizers allowed restitution claims only for property expropriated between February, 1948, and January, $1990 .{ }^{203}$ U nlike the German scheme, one important aspect of the Czechoslovak restitution scheme was that only persons residing in Czechoslovakia were eligible to make restitution claims. ${ }^{204}$ While the Germans were practically forced to favor those living outside of East Germany in their restitution process, ${ }^{205}$ Czechoslovakia instituted a system in which citizens of Czechoslovakia were the primary beneficiaries. Despite political controversy over whether to expand restitution to persons living beyond the Czechoslovak border, the government maintained its policy. ${ }^{206}$ Because the gov-

198. See FRYDMAN ET AL., supra note 184 , at 76 .

199. Id. at 76-77; Mejestrík \& Sojka, supra note 185, at 69-70.

200. See Jan Mladek, The Different Paths of Privatization: Czechoslovakia 1990 - ?, in Privatization in the Transition to a Market ECONOMY: Studies of Preconditions and Policies in Eastern Europe 121, 126 (John S. Earle et al. eds., 1993).

201. See Mejstrík \& Sojka, supra note 185 , at 72 .

202. See id.

203. See Mladek, supra note 200 , at 122 .

204. See id.

205. Most of the people living outside East Germany with restitution claims were once $E$ ast Germans who either fled the Nazi regime or fled from the communist government of the GDR. These people are certainly entitled to compensation for their property, but perhaps for those outside East Germany, a monetary compensation scheme (which was rejected early, see supra notes 73-74 and accompanying text) could have preserved East German ownership while compensating others for their losses.

206. See FrydMAN ET AL., supra note 184, at 77; Mladek, supra note 200, at 125-26; 
ernment maintained a consistent flexible policy which favored its own citizens, Czechoslovak restitution progressed much more smoothly than Germany's and was the fastest method of privatization in Czechoslovakia. ${ }^{207}$

The strategies employed in the Czechoslovak model provide insights into the German process. Czechoslovakia concentrated on its citizens, who consequently retained ownership of their property and were satisfied with the process. A Ithough it would be impossible to implement the same process in Germany due to political and constitutional constraints, the principle behind it is useful. ${ }^{208}$ Czechoslovakia created a system of rules which, while strict, were flexible enough not to require amendments throughout the process, as did Germany's. Citizens of Czechoslovakia were given priority in the allocation of privatization opportunities. Final deadlines for claims were diligently enforced and monetary compensation was a ready alternative to restitution-in-kind from the beginning. Investment was not slowed and restitution progressed relatively smoothly in Czechoslovakia.

These strategies should be considered by other privatizers where restitution is a potential form of transfer. A flexible system which favors citizens of the country and allows them to maintain ownership will foster integration and stability. By designating monetary compensation as a preferred or at least equal method for restitution, privatizers would maintain opportunities for foreign investment. In Germany, a system of monetary compensation would have had the dual effect of allowing East German holders to retain property and of speeding along investment. Future privatizers should take note to avoid a similar lack of integration and a similar inhibition of investment.

3. Direct Sales and Voucher Privatization. The privatizers in Czechoslovakia, like the German privatizers, chose the "Big Bang" approach to mass privatization. ${ }^{209}$ Like German privatization,

Jiri Pehe, The Czech Republic: A Successful Transition, RFE/RL RES. REPS., Jan. 7, 1994, at 74 .

207. See Mejstrík \& Sojka, supra note 185 , at 72 .

208. Because Germany is a unified country, it would be unconstitutional to restrict restitution to those living in East Germany, because as citizens, West Germans would presumably be included in any restitution scheme. See G.G. art. 14. A Iso, politically, the Germans could not deny restitution to people who fled Germany during the Nazi regime.

209. See Jane Perlez, Czechs Move Quickly to Privatization, N.Y. TIMES, Dec. 24, 
Czechoslovak privatization included privatization by sales to private persons and restitution of expropriated properties. ${ }^{210}$ U nlike German privatization, however, the Czechoslovak system combined a variety of methods which created opportunities for citizens of Czechoslovakia to take part in the transformation of the Czechoslovak economy. ${ }^{211}$ The sales of large state-owned enterprises were conducted through a flexible combination of methods, including both direct sales and the voucher privatization method. ${ }^{212}$

Citizens of Czechoslovakia were more involved in direct sales of assets because they were given opportunities to invest. Citizens paid the book value for enterprises, while foreigners paid market value. $^{213}$ A s a result, foreigners usually had to pay much more than citizens for enterprises. ${ }^{214}$ The decision to differentiate between citizens and foreigners allowed for more internal investment in Czechoslovakia. In Germany, on the other hand, foreign and W est German investors were favored, forcing $E$ ast Germans out of the picture. The Czechoslovak solution tended to prefer its own citizens, thus allowing them to maintain ownership in their country and to avoid a colonization from the outside, as occurred in East Germany.

A Iternatively, Czechoslovakia also used the method of voucher privatization. The process of voucher privatization, sometimes referred to as "popularizing privatization," 215 consists of "sales" of shares of privatizing enterprises to citizens. ${ }^{216}$ Citizens of Czechoslovakia paid an administrative fee of about thirty-four dollars to purchase a booklet of investment coupons, which in turn could be exchanged for stock in newly privatized enterprises. ${ }^{217}$ In the first wave of privatization, completed in 1993, more than 8.5 million people "bought" stock. ${ }^{218} \mathrm{M}$ any invested their vouchers

1993, at A 8; see also supra note 32 and accompanying text.

210. See Mejstrík \& Sojka, supra note 185 , at 68-69.

211. See FRYDMAN ET AL., supra note 185, at 80-81.

212. See Mejstrik \& Sojka, supra note 185, at 73; see also FRYDMAN ET. AL, supra note 184 , at 80 .

213. See FRYDMAN ET AL., supra note 184 , at 81 .

214. See id.

215. Holger Schmiedling, Alternative Approaches to Privatization: Some Notes on the Debate, in PRIVATIZATION 95, 106 (Horst Siebert ed., 1992).

216. See id.; FRYDMAN ET AL., supra note 184, at 84-85.

217. See FRYDMAN ET AL., supra note 184, at 84; Philip Crawford, Second Wave of Offerings Will Liquidate State Control, INT'L HERALD TRIB., Nov. 9, 1993, at 7.

218. See Jiri Pehe, Czechoslovakia: Toward Dissolution, RFE/RL RES. REPS., Jan. 1, 
with investment advisors who then created investment funds. ${ }^{219}$ Voucher privatization allowed citizens to participate in the transition of the Czechoslovak economy.

Citizens of Czechoslovakia, as a result, were better prepared for the transition and had more invested in the outcome of the privatization process. The voucher scheme gave citizens a stake in the new market economy; in return, citizen entrepreneurs are now "fiercely loyal to Prague's democratic government." 220 The Czechoslovak privatization effort also progressed quickly in spite of its flexibility. By late 1993, just under two years after the implementation of the Privatization A ct, sixty percent of Czech property $^{221}$ was already in private hands. ${ }^{222} \mathrm{~A}$ Ithough the full effects of voucher privatization are still unknown, ${ }^{223}$ it is clear that the process has successfully transferred ownership into Czechoslovakia's own private sector. The Czech Republic claims that, at the end of 1995, almost eighty percent of its GDP came from the private sector. ${ }^{224}$ The Czechoslovak economy is now probably the healthiest in Eastern E urope. ${ }^{225}$

1993, at $84,87$.

219. See Mladek, supra note 200 , at 131 . These investment funds are similar to mutual funds. The presence of investment funds is vital to the success of a voucher scheme; it enables persons to diversify their risk. The funds can also direct citizens how to invest their own money since none of these citizens have ever experienced investing before. See Schmiedling, supra note 215 , at 103-04. If voucher privatization had been employed in Germany, such funds likely would have been beneficial there as well.

220. Walsh, supra note 6, at 1 . See also Peter Rutland, Privatization in East Europe: A nother Case of Words that Succeed and Policies that Fail?, 5 TRANSNAT'L L. \& CONTEMP. PROBS. 1, 12 (1995) ("A Iso, by giving people an individual stake in the process, it solidified public support for the privatization campaign.").

221. This statistic is for the Czech Republic. The Czech government has continued with the plan instituted by the Federation. See Ron Chepesiuk, The Velvet Divorce, ST. Petersburg Times, Dec. 26, 1993, at 1D. Slovakia halted its adherence to the Czech privatization model and instead adopted one similar to that used in Germany. See Slovak Privatisation Halted, CTK NAT'L NEWS WIRE, Dec. 27, 1995, available on LEXIS, World Library, Curnws File.

222. See Pehe, supra note 206, at 72 . With Czechoslovakia, as opposed to Germany, "private" hands includes the hands of many citizens of Czechoslovakia.

223. Economic consequences of voucher privatization are still questioned by economists who doubt the economic efficiency and economic consequences of the process. See Mejstrík \& Sojka, supra note 185 , at $79-80$. While these results are yet to be seen, what is of interest in this Note is the mechanism of involving the citizens of the privatizing country as an alternative to direct sale of companies.

224. See Prague Transformed, THE E conomist, Nov. 18, 1995, at 17, 19.

225. See The Czech Republic-An Island of (Relative) Stability in East Europe, SD I INSTRUMENT BUS. OUTLOOK, A ug. 15, 1995 available in LEXIS, News Library, Curnws File. 
W hile voucher privatization was successfully carried out in the former Czechoslovakia, 226 it was considered, but never attempted, in East Germany. Wolfgang U IIman, an East German leader and Treuhand insider, wanted to try a voucher scheme which would have entitled each East German to a share of the country's assets. ${ }^{227} \mathrm{He}$ believed that if the citizens were given a stake in the new market economy, then they would have had greater incentives to help make the new economy succeed. ${ }^{228}$ The German government rejected the suggestion, because a voucher system would only have brought money to the people with vouchers, and would not attract foreign investment or technology. ${ }^{229}$ Even acknowledging the need for foreign capital, however, a more flexible plan, which utilized foreign investment but also secured some domestic participation, would likely have provided better results for the Germans. $^{230}$

Politicians and critics of voucher privatization defend the decision not to use vouchers in East Germany for two principal reasons: voucher privatization is slower than the German method, and voucher privatization does not attract foreign capital. ${ }^{231}$ Further, the German decision was defended on the grounds that other former communist nations needed a system like voucher privatization, which distributed ownership to the people, in order to create a property rights regime. Since such a regime (and an accompanying democracy) already existed in Germany, they argued, no such method was necessary. ${ }^{232}$ That attitude-that East Germany was

226. Privatization in general has been more successful in the Czech Republic than in Slovakia since the breakup of the federation. See Chepesiuk, supra note 221, at 1D.

227. See Walsh, supra note 6 , at $\mathrm{H} 1$.

228. Id.

229. The German government never acknowledged the fact that foreign investment is not always good. While the influx of capital from foreign investment is good for the economic structure, foreign investors do not always "promote the interests of the local population." Chua, supra note 16, at 264 n.333.

230. See Mejstrík \& Sojka, supra note 183, at 74-80 (acknowledging the risks and potential problems of voucher privatization, but also recognizing the positive aspect of giving people ownership in their country); Schmiedling, supra note 197, at 106-07.

231. See SIEBERT, supra note 31, at 97-98; Schmiedling, supra note 213, at 106-107; Michal Mejstrik, Where We Are Headed: The Case of Czechoslovakia, in COMRADES Go PRIVATE 65, 77 (Michael P. Claudon \& Tamar L. Gutner eds., 1992). Siebert also cited protection of $E$ ast German jobs as a reason for rejecting voucher privatization. See SIEBERT, supra note 31, at 99. However, the unemployment rate for E ast Germans with the chosen method of privatization was great indeed. See supra notes 129-36 and accompanying text.

232. See SIEBERT, supra note 31 , at 98. 
entirely distinct from other privatizing countries-epitomizes the problem with the German system. West Germany was a democracy and already had established property rights and a market system, but East Germany was not. Consequently, some measures based upon the experience of Eastern European countries would have fostered long-term social and economic integration in the reunified Germany.

Critics acknowledge that E ast Germans deserve some ownership in their enterprises. ${ }^{233}$ They claim, however, that this would have forced the Treuhand essentially to give away enterprises, which would have disadvantaged East Germans in the long run. ${ }^{234}$ They claim that the German model was beneficial because privatization progressed quickly and attracted ample foreign investment, which, in turn, strengthened the German economy. ${ }^{235}$ While in the short term this may be true, East German integration remains a long-term problem. The apologists recited the rhetoric of long-term benefits, but the plans actually focused on the short term. Some short-term efficiency should have been sacrificed in order to create a more stable democratic and economic order, one in which the citizens of East Germany could meaningfully participate. ${ }^{236}$

A flexible program that included aspects of both the actual German privatization model and voucher privatization would have benefitted the people of East Germany. ${ }^{237}$ If the Treuhand had reserved some portion of East German firms for distribution to the East Germans, and sold the remainder to foreign investors, it would have attracted much-needed capital while also involving East Germans in the ownership of privatized enterprises. By pre-

\footnotetext{
233. See id. at 99.

234. See id. at 100-01.

235. See id. at 103-04.

236. See Chua, supra note 16, at 296-97 ("[S]ome or all of the regulations I am proposing will likely be less than optimally efficient from the short-run perspective. . . Waiting for the trickle-down is not sound strategy in the developing world.").

237. Such an alternative privatization model was proposed by Gerlinde and $\mathrm{H}$ ansWerner Sinn, and is called the "participation model." See GERLINDE SINN \& HANSWERnER SINN, JUMPSTART 81-86 (1992). Like the voucher method, this model would retain some ownership for the East German people. It would have allowed the Treuhand to retain some small portion of ownership in each of the privatized enterprises, which would then have been distributed to the citizens of the former GDR. See id. This method was never attempted by the German government. See also Mejstrík, supra note 231, at 75-81 (also suggesting a part-voucher, part-foreign investor privatization scheme).
} 
serving some ownership for the East Germans, the "colonial" mentality could have been avoided and integration better fostered. This is not to suggest that voucher privatization would be without problems, nor that vouchers would have solved all of Germany's current problems. Rather, the point is that the effort by the Czechoslovak government to focus on the distributional consequences of privatization has helped the Czech Republic avoid larger problems of integration, and in turn, political and economic instability. The same type of model would serve the developing world in conducting large-scale privatizations to create stable democracies and market economies, into which all the citizens of developing countries might be more easily integrated.

\section{B. Southeast A sia and L atin A merica}

In the Latin American and Southeast A sian privatization context, lessons can be learned not from what countries in these regions have done right, but from what they have done wrong. Privatizations have been conducted in Latin A merica and Southeast A sia for decades. ${ }^{238}$ In Latin A merica, privatization problems have arisen because of drastic class differences. ${ }^{239}$ Similar issues have arisen in Southeast A sia as a result of ethnic group division. ${ }^{240}$ While these developing regions are obviously very different from Germany (even more so than from the countries of Eastern E urope), important similarities nevertheless exist. Specifically, just as Latin A merica and Southeast A sia are comprised of starkly different social groups, Germany consists of the East and West Germans.

Professor A my Chua's examination of privatization in the context of group conflict provides some valuable lessons for Germany. ${ }^{241}$ In The Privatization-Nationalization Cycle: The Link Be-

238. See Chua, supra note 16 , at $227-256$ (describing history of privatization and nationalization).

239. See, e.g., Fernando H. Cardoso \& Enzo Faletto, Dependency \& DevelOPMENT IN LATIN AMERICA 27 (M arjory Mattingly U rquidi trans., 1978) (referring to the style of political confrontation in crisis situations as well as the shape and functions of workers unions as illustrations of "class situations").

240. See Chua, supra note 16 , at 244-56.

241. See generally Chua, supra note 16. Professor Chua examined the privatizationnationalization cycle in the developing countries of Latin A merica and Southeast A sia. Like the strategies proposed in this Note, Professor Chua's research suggests privatization methods which encourage the consideration of the distributional consequences of privatization. 
tween Markets and Ethnicity in Developing Countries, Professor Chua examines the tension between privatization and the ethnic, nationalist structures that characterize most developing countries. She concludes that a recurring oscillation exists between nationalizing and privatizing regimes throughout the developing areas of Latin A merica and Southeast $A$ sia. ${ }^{242}$ Drawing on a wide range of historical and sociological data, Professor Chua makes a persuasive case that the cause of this cycle lies in the interplay between privatization and ethnic group conflict. Free-market policies in these regions historically have resulted in the disproportionate prosperity of particular, ethnically identifiable groups. As a result, ethnically charged-and therefore extremely potent-nationalist movements repeatedly have arisen in the wake of privatization programs. $^{243}$

A ttempts by foreigners to take control of newly privatized nations, a practice similar to colonization, cause nationalist ideologies to arise and to disrupt privatization. ${ }^{244}$ The driving force of a nationalist ideology is a sentiment not only against foreign investors, but also against "foreigners within," 245 i.e., different groups who share the same country. In order to maintain a stable system, measures must be undertaken to combat or curb these forces of nationalism. ${ }^{246}$ These measures, in turn, must focus on the distributional consequences of privatization.

This theory applies to Germany as well. While East Germans and West Germans are not different ethnic groups under most traditional analyses, ${ }^{247}$ they are two distinct groups who share the same country. Different national identities in the two German states developed over forty-five years. ${ }^{248} \mathrm{Life}$ under a communist system changed the East Germans. They lived under a different set of laws, with a different social system, a pattern of political oppression, a struggling economy, and a low standard of living. ${ }^{249}$

242. See id. at 279-84.

243. See id.

244. See id. at 279.

245. Id.

246. See id. at 288.

247. See Donald L. Horowitz, EthniC Groups In CONflict $51-52$ (1985) (defining ethnicity as a "myth of collective ancestry," based on birth and blood).

248. See laurence H. McFalls, Communism's Collapse, Democracy's Demise? 143 (1995).

249. See Landua, supra note 112 , at $92,97$. 
Furthermore, East and West Germans think of themselves as different groups. ${ }^{250}$ The Ossis are the Germans from the East and the Wessis are those from the West. The Ossis and Wessis hold deep prejudices against each other. ${ }^{251}$ The O ssis "tend to see westerners as exploiters, and [Wessis] ... regard the east as an unworthy sinkhole for their tax money." 252 Moreover, there are significant psychological differences between the East and the W est. ${ }^{253}$

These differences have deepened since reunification. ${ }^{254}$ In a survey of East and West Berlin bureaucrats, "nearly every third respondent from $E$ ast $B$ erlin counted 'citizens of the new $L$ änder as a distinct group of people whose legitimate interests were being unduly neglected." ${ }^{255}$ O ne commentator argues that the current political problems in Germany have been caused by the "fundamental conflict between East and West Germans' cultural values." ${ }^{256}$ Because Germans view themselves as two distinct groups, theories of privatization concerning group conflict in Southeast A sia and Latin A merica are applicable. ${ }^{257}$

East Germans have witnessed Western prosperity and are generally unsatisfied with their relative situation. ${ }^{258}$ A s West Germans- "foreigners within"-and foreigners have bought much of the land and enterprises in the East and unemployment has skyrocketed, feelings of animosity toward these investors have grown and a certain East German "nationalism" has arisen. While privatization in Germany is not in great danger of collapse, focus on the group differences like those that were largely ignored in Latin A merican and Southeast A sian privatizations would promote longterm stability and integration. Today's privatizers, including those

250. See Kuechler, supra note 19 , at $47-49$.

251. See Baylis, supra note 12 , at $86-87$.

252. Cowell, supra note 135 , at A 1 .

253. See Baylis, supra note 12 , at $86-87$.

254. See, e.g., MCFALLS, supra note 248, at 152-54.

255. Eckhard Schröter, When Cultures Collide: The Case of Administrators from East and West Berlin, in StUdies IN GDR CULTURE AND SOCIETY 13.

256. MCFALLS, supra note 248 , at 160 .

257. The fact that East and West Germans view themselves as distinct groups also exacerbates the distributional consequences of privatization. See ALLEN BUCHANAN, SECESSION 51 (1991) (arguing that whether a group regards itself as a victim of discriminatory redistribution depends on how it regards its own identity in relation to other groups).

258. See supra notes $116-27$ and accompanying text. 
in Eastern Europe, should heed these warning signs and study their predecessors' experiences to prevent them from drifting into a "privatization-nationalization cycle." 259

In order to combat the destructive forces of nationalism, Professor Chua offers suggestions applicable in Germany and in other parts of Eastern Europe. Her suggestions, if implemented, would accomplish two things: they would give people a sense of ownership in their country, as has voucher privatization in the Czech context; and they would give critical attention to the distributional consequences of privatization. First, Chua suggests ownership restrictions aimed at limiting the ownership interests of both foreign investors and "foreigners within." 260 These restrictions run counter to the instincts of many of today's commentators and privatizers because they necessarily inhibit foreign investment. ${ }^{261} \mathrm{H}$ owever, they could help to structure incoming foreign capital in a way that allows citizens to retain some ownership, thus avoiding the nationalist reaction that often arises from large shares of foreign ownership. ${ }^{262}$ In Germany, this would have included measures for East Germans to retain some ownership in their country to avoid becoming an effective "colony" of the West.

Professor Chua also suggests government subsidies for small, local investors. ${ }^{263}$ She compares this method to voucher privatization and concludes that it will have an effect similar to that of ownership restrictions, maintaining a stake for citizens of the privatizing country instead of parsing it out to foreigners. ${ }^{264}$ Subsidies would likely have proven valuable in East Germany. If the Treuhand had expended some of the money it spent on the search for foreign investors on subsidies for entities that could have been purchased and managed by $E$ ast Germans, integration of $E$ ast Germans into the nascent economy would have been facilitated and the colonization effect could have been avoided. Similarly, Chua suggests allowing labor to become involved in the privatiza-

259. Chua, supra note 16 , at 226 .

260. Chua, supra note 16 , at 289-96.

261. Cf. U Irich Hiemenz, Comment on Andras Inotai, Experience with Privatization in East Central Europe in Privatization, supra note 197, at 183, 184; Schmiedling, supra note 197, at 107.

262. See Chua, supra note 16 , at 289.

263. See id. at 293.

264. See id. 
tion process. ${ }^{265}$ Provisions for employee buyouts or for allocation of shares to employees of a privatizing enterprise are manners of implementing such a scheme. ${ }^{266}$ Finally, Professor Chua suggests requirements that foreign investors bring prompt tangible benefits to the local community, perhaps mandated in purchase agreements or other contractual obligations. ${ }^{267}$ A lthough these measures may lead to less short-term economic efficiency, more stable private regimes will result in the long run. ${ }^{268}$ Ignoring suggestions like these in the past has led to, and most likely will again lead to, a return to nationalization.

The same forces lead to political instability. U nless kept in check, group tensions have the potential to undo all the good that has been accomplished through privatization. While transferring enterprises to private hands is the goal of privatization, a stable regime is a prerequisite. Ignoring the distributional consequences of privatization and exacerbating group conflict will likely cause instability. The seeds of this phenomenon are exhibited in Germany, a stable, western country. The countries of the developing world and the former Soviet bloc would do well to heed these warning signs.

\section{CONCLUSION}

German privatization was a mammoth task that has been, by traditional measures, quite successful. There are several areas, however, in which the legal structures chosen by the German privatizers have created problems for the German people. East German integration into a unified German economic, political and social life has been inhibited as a result of the colonial mentality caused by these structures. This Note has pointed out deficiencies in the German system and their effects on the East German people.

It is too late for Germany to employ alternative mechanisms, but today's privatizers can learn a great deal from the decisions of

265. See id. at 298.

266. See id. at $297-98$.

267. See id. at 296.

268. See id. at 296-97 (recommending the wide, quick and visible distribution of the benefits of privatization on the general populace over the "spectacle of a privatized company" reaping profits for foreigners and a few wealthy domestic elite); see also Jeffrey Prescott, Book Note, Government Efficiency and the Market Metaphor, 105 YALE L.J. 2019, 2024 (1996). 
the privatizers who have engaged in the world's largest such venture. While no two countries face identical circumstances, the same principal task must be accomplished in privatization: the transfer of state-owned property to the private sector. Because this basic task is the same, comparative examples are a valuable tool to improve techniques for today's privatizers. This $\mathrm{N}$ ote has focused on two comparative illustrations, but countless others are useful as well.

The German, Czech, Latin A merican, and Southeast A sian examples suggest mechanisms to foster long-term stability of a market system and integration of the people. Each country must tailor specific methods to fit its needs, but today's privatizers should give central attention to the distributional consequences of privatization. This can be accomplished by involving all groups of citizens in the privatization process. Involving these citizens in the privatization process creates a national stake in the new economy, enhances the strength of the newly-instituted economic regime, and fosters stability in a government supported by its citizens. 